九州大学学術情報リポジトリ

Kyushu University Institutional Repository

\title{
A revision of the subfamily Psyllinae from Japan. II (Hemiptera : Psyllidae)
}

Miyatake, Yorio

Entomological Laboratory, Department of Agriculture, Kyushu University

https://doi.org/10.5109/22711

出版情報 : 九州大学大学院農学研究院紀要. 13 (1)，pp.1-37，1964-03. Kyushu University バージョン：

権利関係 : 
Journal of the Faculty of Agriculture, Kyushu University, Vol. 13, No. 1

March 30, 1964

A revision of the subfamily Psyllinae from

Japan. II (Hemiptera : Psyllidae) *

Yorio MiYATAKe

23. Psylla haimatsucola Y. Miyatake, sp. nov.

(Fig. 1, A--D)

- : General colour of head and thorax yellowish brown to reddish brown; median line and discal impressions of vertex, two apical segments of antennae, most part of pronotum, apical half of praescutum, two pairs of longitudinal stripes on scutum, thorax laterally, femora (usually basal two-thirds), and meracanthi black; antennae except two apical segments, tips of genal cones, and tarsi dark brown. Forewings hyaline, with veins light brown in the basal half and dark brown to black in the apical half (Fig. 1, A). Abdomen mostly black or pitchy black; male genital segments more or less brownish, with forceps reddish brown mostly and shiny black at apex ; female genital segments mostly black in profile, with ventral valve a little yellowish to reddish brown in the dorsal half along dorsal margin, continuing diagonally to ventral margin.

Head nearly as wide as thorax, strongly deflexed; vertex rather small, half as long as broad, convex, discal impressions rather deep, with posterior margin moderately incised ; genal cones (Fig. 1, B) slender, long, nearly as long as vertex on median line or longer, vertical, slightly divergent apically, blunt at apex, with long, white, dense, pubescence; occiput covered with pronotum; antennae moderately long, slender, almost as long as width of forewings, pubescent, with two apical setae of the same length, relative lengths of the antennal segments as 2 : $3: 8: 5: 5: 5: 5: 5: 2: 3$.

Thorax well arched, robust, without pubescence ; pronotum slightly hidden under head anteriorly, swollen dorsad above plane of vertex; scutum short, much shorter than half as long as wide, about $1 \times 2.3$. Legs stout, with pubescence; posterior tibia with a minute, blunt, basal spur, with 1 outer and $t$ inner apical spines; proximal segment of posterior tarsus with a pair of apical spines. Forewings long, elongate, much longer than twice as long as wide, narrowed basally, with anterior margin sparsely pubescent; pterostigma well defined, basally closed, slightly over as long as width of forewings; Rs sinuate, upcurved in the basal half and downcurved in the apical half; $\mathrm{Cu}_{1}$ and $\mathrm{M}_{3+1}$

* Contribution Ser. 2, No. 183. Entomological Laboratory, Kyushu University. 
subparallel to each other; first marginal (cubital) cell rather large, high, somewhat quadrilateral ; second marginal (medial) cell longer than first, long triangular; relative lengths of the veins $\mathrm{M}-\mathrm{t}-\mathrm{Cu}, \mathrm{M}, \mathrm{M}_{1+2}, \mathrm{M}_{3+4}, \mathrm{Cu}, \mathrm{Cu}_{2}$ as $4: 20: 11: 12$ $: 12: 8$. Abdomen (excl. genital segments) exceedingly short, half as long as width of forewings, with tergites scarcely pubescent, with sternites densely pubescent.

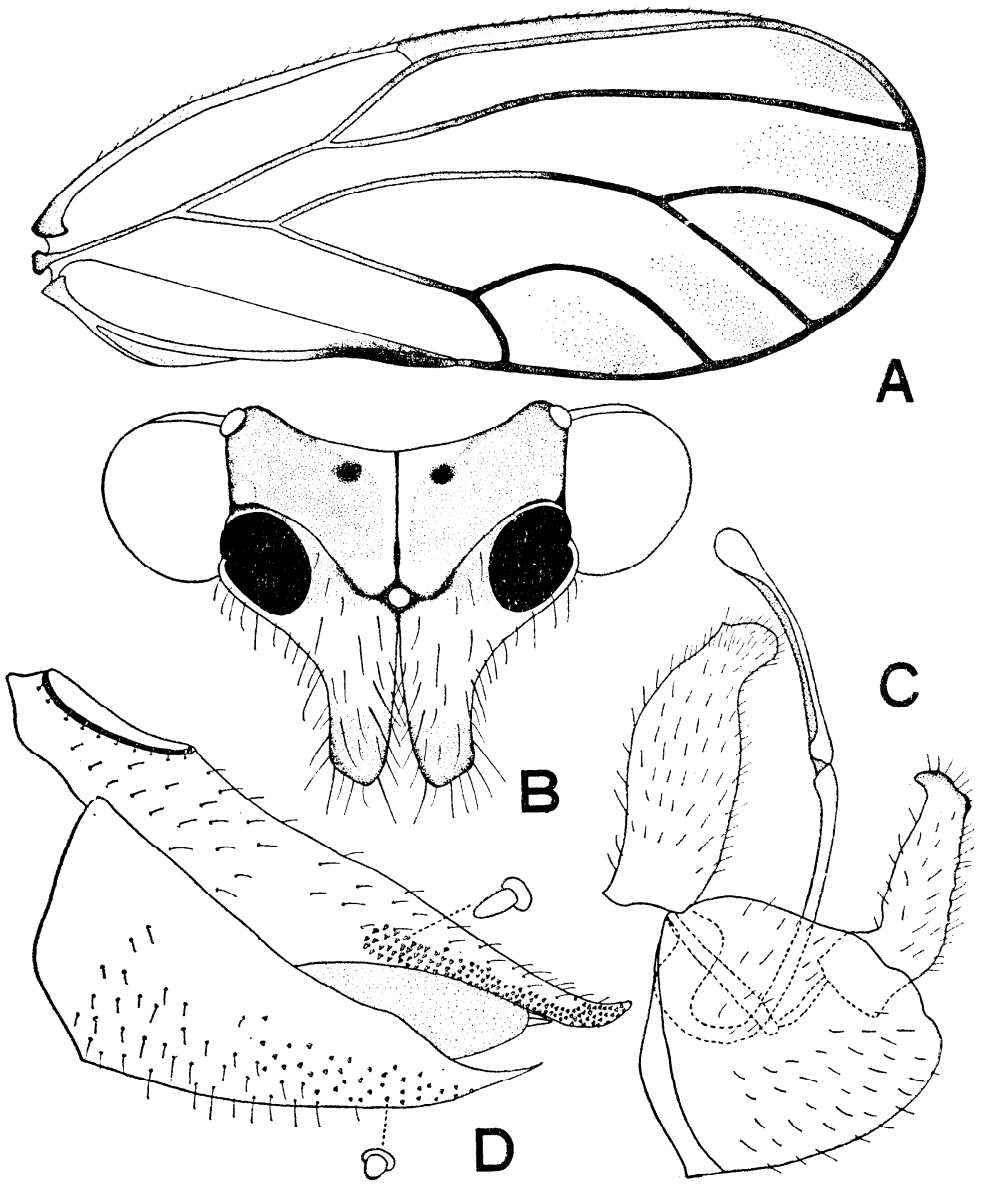

Fig. 1. Psylla haimatsucola Y. Miyatake, sp. nov.

A. Forewing, B. Head (antennae excluded), frontal aspect, .

C. Male genitalia, lateral aspect. D. Female genitalia, lateral aspect.

Male genital segments (Fig. 1, C) moderately large; proctiger large, longer than forceps, produced cephalad at base anteriorly, broadened midway, strongly bent caudad near apex almost in right angle, pubescent, with surface slightly rugose dorsally; anus opened dorsad ; forceps large, rather slender in lateral view, broad basally after compression, dorsal margin rather straight, tapering to sharply acute apex, turned strongly cephalad at apex, in caudal view broad, 
very slightly arched, acute apically, densely pubescent ; aedeagus long, sinuate, with first segment broad at base, z-shaped, with second segment slender, globular at apex, relative lengths of first segment and second segment $22: 13$; subgenital plate moderately large, subtriangular in profile, almost as high as proctiger, ventral margin nearly straight, dorsal margin sinuate, with anterior part divided with suture longitudinally, with surface pubescent, in caudal view bifurcate strongly. Female genital segments (Fig. 3, D) much longer than the rest of abdomen, rather slender; dorsal valve distinctly longer than ventral, slender, in profile dorsal margin sinuate near midpoint, apical third very slender, slightly upcurved and bluntly acute at apex, pubescent; anus rather amall, about one fourth as long as dorsal valve in larger diameter; inner valve slightly longer than ventral; ventral valve rather broad, strongly upturned and acute at apex, with dorsal margin sinuate, pubescent.

Length of body $\hat{o} 1.8-1.9 \mathrm{~mm}, 2.2-2.5 \mathrm{~mm}$; length of forewing $2.7-2.9 \mathrm{~mm}$, $2.7-3.1 \mathrm{~mm}$; length of antenna $1.0-1.1 \mathrm{~mm}, 1.0-1.2 \mathrm{~mm}$.

Distribution: Japan (Honshu, Hakkaido).

Holotype ( $)$ : Kurodake (1984 m), Mts. Daisetsu, Kamikawa-gun, Hokkaido, 21. vii. 1962, Y. Miyatake leg. (on " Haimatsu "-Pinus pumila Regel).

Paratypes : 10 so 89 , the same data as the holotype ( 2 $29 \%$ on slides). 5 if ' the same locality as the holotype, 22. vii. 1962, Y. Miyatake leg. $1: 2 \div$, the same locality as the holotype, 23. vii. 1962, Y. Miyatake leg. 132 , Utsukushiga-hara, Mts. Daisetsu, Kamikawa-gun, Hokkaido, 22. vii. 1962, Y. Miyatake leg. 2 S $2 \%$, Mt. Daisetsu, Kamikawa-gun, 22-24. vii. 1959, T. Kawarabata leg. 3 4 Meakan-dake $(1503 \mathrm{~m})$, Akan-gun, Hokkaido, 30. vii. 1962, Y. Miyatake leg. 3 5 积, Meakan-dake, Akan-gun, Hokkaido, 5. vii. 1958. S. Miyamoto leg. 4 6 69 , Aizankei $(1000$ m), Kamikawa-gun, Hokkaido, 17. vii. 1962, Y. Miyatake leg. 131 , Aizankei, Kamikawa-gun, Hokkaido, 18. vii. 1962, Y. Miyatake leg. 1 \% , Aizankei, Kamikawa-gun, Hokkaido, 18. vii. 1962, T. Saigusa leg. 1 ', Aizankei, Kamikawa-gun, Hokkaido, 24. vii. 1962, Y. Miyatake leg. 19, Ashoro, Tokachi, Hokkaido, 31. v. 1955, M. Takahashi leg. 202 , Nukabira $(600 \mathrm{~m})$, Tokachi, Hokkaido, 3. viii. 1962, Y. Miyatake leg. (light trap). 4 3 3 , Nukabira, Tokachi, Hokkaido, 13. vi. 1959, M. Tonosaki leg. 1s, Kitazawa-Senjyodake, Yamanashi Pref., 27. vii. 1959, Y. Miyatake leg. 312, Sen jyodake-Shirane-kitadake, Yamanashi Pref., 28-29. vii. 1959, Y. Miyatake leg. 19, Tsubakuro-dake, Nagano Pref., 18. viii. 1962, T. Saigusa leg.

Host plants: " Haimatsu "-Pinus pumila Regel [Pinaceae]; adults, confirmed at Mts. Daisetsu (2000-2200 m) by me in July, 1962, Meakan-dake in Hokkaido by S. Miyamoto in July, 1958 and by me in July, 1962, Senjyodake-Shirane-kitadake, Yamanashi Pref. by me in July, 1959. "Ezomatsu"-Picea jezocnsis Carr. [ Pinaceae] ; adults, confirmed by me at Aizankei in Hokkaido in July, 1962.

Differs from Psylla prohaskai Priesner 1927, which is found up the mountain ranges of the Alps in Austria on Pinus montana in being larger, in having the genal cones more slender and longer, over as long as the vertex, in having the forewings more elongate, and in having the proctiger much longer than the forceps in male, in lateral aspect strongly curved caudad, and in having the longer dorsal valve in the female genital segments, more slender and conspicuously attenuate apically. 


\section{Psylla japonica Kuwayama, Jr.}

Psylla japonica Kuwayama, Jr., 1955, Mushi, Fukuoka 29: 1.

Distribution: Japan (*Hokkaido, Honshu, Shikoku, Kyushu).

Specimens cxamined: $1 \hat{\jmath}$ ९, Kuboteyama, 15. vii. $1938 ; 1$, Inugatake, 12. vii. 1938 ; Fukuoka Pref., Hori, Kawahara \& Yasumatsu leg. 2 \%甲, Nakano-onsen, Handa-kogen, Bungo, 20. vii. 1929, Esaki \& Fujino leg. 13 \& 8 9 , 17. vii. 1929, Esaki \& Fujino leg.; 1今, 30. v. 1944, Esaki \& Yasumatsu leg.; 1今, 19. v. 1939, H. Hori leg. ; 4 exs., 27. v. 1938, Esaki, Nomura \& Yasumatsu leg.; 1 ex., 20. v. 1961, A. Habu leg. ; 6329 , 7. vi. 1959, Y. Miyatake leg.; 1 , 3. vi. 1958, 1\%, 5. viii.

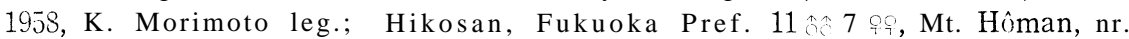
Fukuoka, 13. vii. 1959, Y. Miyatake leg. 1^̊, Mt. Kujuh, Ôita Pref., 18. vii. 1958, Y. Miyatake leg. 1今, Mt. Ishizuchi, Iyo, 18. x. 1952, K. Sasaki leg. $6 \hat{8} 3$ 우, Mt. Sara, Iyo, 16. vii. 1954, K. Sasaki leg. 1今, Dosu-pass, Sawadani-mura, Awa, 4. viii. 1956, I. Hiura leg. 1f, Kuroson, Tosa, 10. viii. 1624, T. Hshihara leg. 3 : 7., Mt. Dogo, Hiroshima Pref., 4. vii. 1954, T. Ishihara leg. 2 9f, Daisen, Tottori Pref., 26. v. 1954, S. Kimoto leg. 1今, Enayama, Mino, 15. viii. 1919, K. Takeuchi leg. 1\%, Mt. Hira, Shiga Pref., 13. vi. 1957, 0. Satô, leg. 19, Bessho, Kyoto, 31. v. 1953, 0. Satô leg. $1 \delta \mathbf{1}$ \&, Mt. Gomadan, Wakayama Pref., 2. viii. 1957, Y. Shibata leg. 1) Hakusan, Ishikawa Pref., 29-31. viii. 1960, T. Hidaka leg. 1? 3 , Hirayu, Gifu Pref., 28. vii. 1959, M. Miyatake leg. 1., Mt. Tanigawa, Gunma Pref., 23. vii. 1961, T. Kawarabata leg. 2 -, Hirokochi. Yamanashi Pref., 31. vii. 1959, Y. Miyatake leg. 9 - Takada-Ohdake, Aomori Pref.,1ł. vii. 1962, T. Saigusa \& Y. Miyatake leg. 46 3099, Aizankei, Kamikawa. gun, Hokkaido, 17-18. vii. 1962, Y. Miyatake leg. 6 399, Mt. Daisetsu, 22-2-L vii. 1959, T. Kawarabata leg. 5329 , Kurodake, Mts. Daisetsu, 20-21. vii. 1962, (on snow valley), Y. Miyatake leg.

1 ype-scricscxamined: holotype $(3)$ from Nakano-onsen in the collection of the Hokkaido National Agricultural Experiment Station and allotype (?) f t-om Hikosan in the collection of Kyushu University.

Host plants: “Urihada-kaede "-* Acer rufincrve Sieb. et Zucc. [Aceraceae ; adults, confirmed at Mt. Hôman, Fukuoka in July, 1959 by me; nymphs \& eggs, confirmed at Mt. Hôman in March, 1960 by me. "Ogarabana "- * Acerukumm. ducnse Trautv. et Mey. [Aceraceae]; nymphs \& adults, confirmed at Aizankei, Hokkaiddo in July, 1962 by me.

\section{Psylla albovenosa Kuwayama}

Pylla albovenosa Kuwa yama, 1908, Trans. Sapporo Nat. Hist. Soc. 2 :176.

Distribution: Japan (Honshu, Shikoku, Kyushu).

Specimens cxamined: 2 19, Mt. Nyuhgasa, Nagano Pref., 29. vii. 1962, S. Miyamoto leg. $1410 \uparrow, 7-14$. vii. 1959, K. Morimoto leg. ; 2212 \% 5. viii. 1959, S. Miyamoto leg.; 2 ふ̊̊, 3-8. viii. 1959, H. Kamiya leg.; Karuizawa, Nagano Pref. 911 , Yumoto, Nikko, Tochigi Pref., 9. vii. 1961, K. Morimoto leg. 1:, Nasu, Tochigi Pref., 20. viii. 1957, S. Hisamatsu leg. 6 乞 3 ค, Mt. Dogo, Hiroshima Pref., 4. vii. 1954, T. Ishihara leg. 1 , Minaminoma, Awa, 20. vii.

\footnotetext{
* Asterisk shows a new record in this paper.
} 
1952, S. Miyamoto leg. 1 \&. Mt. Sara, Iyo, 16. vii. 1954, K. Sasaki leg. 1 Omogokei, Iyo, 5. ix. 1953, K. Sasaki leg. 1 ㅇ, Mt. Ishizuchi, Iyo, 18. x. 1952, K. Sasaki leg. 4 ồ 4 웅, 17. vii. 1929, Esaki \& Fujino leg. ; 1 है, 20. v. 1951, A. Habu leg.; 1 , 13. v. 1955, Esaki, Yasumatsu \& Hirashima leg. ;1 \%, 14. vi. 1959, K.

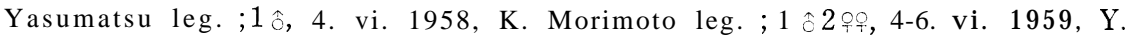
Miyatake leg. ; Hikosan, Fukuoka Pref. 1ㅇ, Mt. Wakasugi, nr. Fukuoka, 26. viii. 1929, T. Esaki leg. 2 ồ, Kyusui-kyô, Ôita Pref., 21. v. 1962, T. Saigusa leg.

Typc-series examined : 2 우 from Hakone (vii, 1903), in the Entomological Institute of Hokkaido University.

Host plant: “Zumi "-*Malus Sieboldii Rehd. [Rosaceae] ; adults, confirmed at Yumoto, Nikko in July, 1962 by K. Morimoto.

\section{Psylla tobirae Y. Miyatake, sp. nov.}

(Fig. 2, A-D)

- General colour green to greenish brown; lateral portion of occiput, anterior margin of praescutum, stripes on scutum, postnotum of metathorax, stripes of abdominal tergites and large part of female genitalia dark brown to black; antennae yellowish brown, with two apical segments black, with tips of segments III to VIII dark brown to black; eyes brown to dark brown; ocelli yellowish orange. Forewings hyaline, rather distinctly brownish at apex of clavus, with veins white to yellowish brown in the basal half and black to dark brown in the apical half (Fig. 2, A); apical spines of posterior tibia and tarsus black.

Head (Fig. 2, B) moderate in size, nearly vertical; vertex slightly longer than half as long as wide on median line, with anterior margin raised near frontal ocellus, with posterior margin scarcely incised, shortly pubescent anteriorly, above plane of pronotum; genal cones as long as vertex or slightly longer, typically blunt at apex and divergent, with sparse but long hairs, somewhat deflexed from plane of vertex; occiput visible in caudal view laterally; frons well covered with vertex, not visible; antennae long, slender, nearly 1.5 times as long as width of head, with 1 long and 1 short apical setae, with segment III long, relative lengths of the antennal segments as $3: 3: 11: 7: 6: 6: 5: 4: 2: 3$.

Thorax robust, arched, not pubescent, slightly rugose ; pronotum subvertical, strongly arched, with deep depressions laterally; praescutum shorter than wide, about $1.3 \times 2$; scutum about half as long as wide; scutellum rather large, 0.3 times as wide as scutum, subrectangular. Legs long, stout, hairy; posterior tibia without prominent basal spur, with 2 outer and 3 inner apical spines; proximal segment of posterior tarsus with a pair of apical spines; meracanthus short, slender, projected ventro-caudad, acute at apex. Forewings elongate, narrowly rounded apically, about 2.4 times as long as wide, broadest near midpoint, with anterior margin hairy to tip of pterostigma; pterostigma long and broad; Rs sinuate ; marginal cells large, first marginal (cubital) cell half as high as wide; relative lengths of the veins $\mathrm{Cu}+\mathrm{M}, \mathrm{CU}, \mathrm{Cu}_{2}, \mathrm{M}_{1+2}$ and $\mathrm{M}_{3+4}$ as $1: 2.5: 1: 2.8$ : 2.4. Abdomen(excl. genital segments) short, nearly as long as width of head, bare dorsally and pubescent ventrally.

Male genital segments (Fig. 2, C) large; proctiger rather stout, with anterior margin almost straight, with posterior margin strongly rounded, narrowed apically, truncate horizontally at apex ; forceps in lateral view broad at base, curved 
caudad at basal third, with margins almost parallel to blunt apex, in caudal view slightly arched to subacute apex, narrow basally and broad medially, with inner face with retrorse, strong setae; aedeagus broad at base, swollen at tip, with first segment 1.5 times as long as second; subgenital plate small, almost as high as proctiger. Female genital segments (Fig. 2, D) distinctly longer than the rest of abdomen, with long pubescence ; dorsal valve slender, attenuate and granulated on the surface in the apical third, conspicuously upturned and blunt apically, with dorsal margin more or less sinuate; anus small, in larger diameter nearly 0.3 times as long as the rest of dorsal margin; inner valve almost as long as dorsal, sharply acute; ventral valve narrow apically and slightly upturned at apes, with
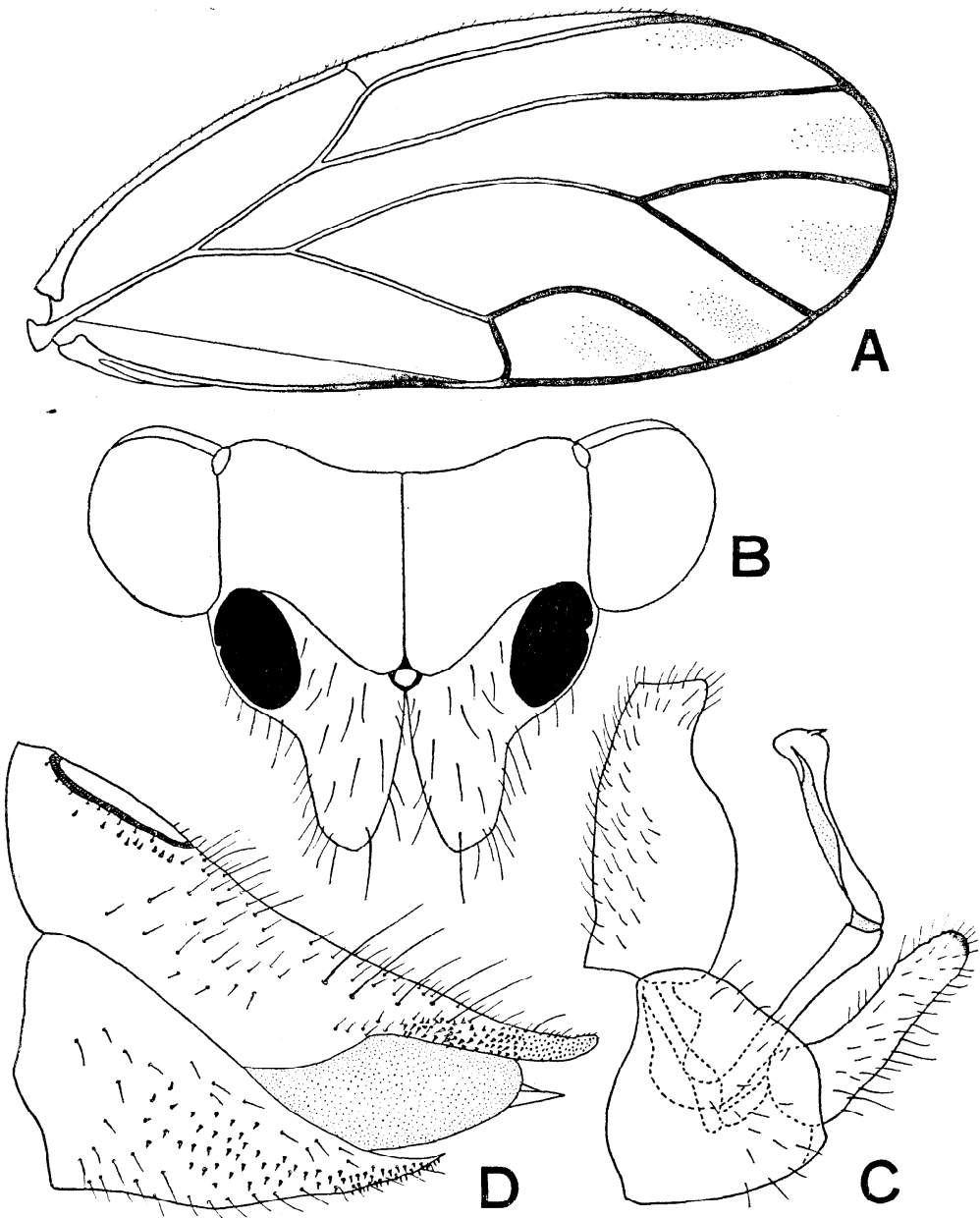

Fig. 2. Psylla tobirae Y. Miyatake, sp. nov.
A. Forewing, $\subseteq$.
B. Head (antennae excluded), frontal aspect, -

C. Male genitalia, lateral aspect.

D. Female genitalia, lateral aspect. 
dorsal margin incised, with ventral margin slightly incised ventrally in proximal half, abruptly turned dorsad to apex.

Length of body $1.7-1.8 \mathrm{~mm}, \odot 2.1-2.6 \mathrm{~mm}$ (to tip of folded wings $\hat{0} 3.0$ $3.1 \mathrm{~mm}$, $3.3-3.8 \mathrm{~mm}$ ); length of forewing $\& 2.5-2.9 \mathrm{~mm}, \$ 2.7-3.0 \mathrm{~mm}$; length of antenna $1.2-1.3 \mathrm{~mm}$, ㅇ $1.2-1.3 \mathrm{~mm}$.

Distribution : Japan (Kyushu, Shikoku).

Holotype ( ) Hirao, Fukuoka City, Kyushu, 21. v. 1958, Y. Miyatake leg. (on Pittosporum Tobira Ait.).

Paratypes: 7 11우, the same data as the holotype on the same host. 101 10. ii. $1958 ; 1$, 9. iii. $1958 ; 6$ os 7 우 ( 2 ô 2 우 on slides), 20. iii. 1959 ; Hirao, Fukuoka city, Kyushu, Y. Miyatake leg. 2 \%ᄋ, 30. iii. 1958; 1 2 \%?, 13. iii. 1959 ; Mt. Tachibana, Fukuoka City, Kyushu, Y. Miyatake leg. 4 수 7 우, Ashizuri, Tosa (Kochi Pref.), Shikoku, 3. v. 1953, K. Sasaki leg. 1ㅇ, 20. vi. 1953; 3 s尺 2 , 30. vi. 1953; Tarumi, Matsuyama City, Shikoku, K. Sasaki leg.

Host plant: “Tobera "-Pittosporum Tobira Ait. [Pittosporaceaej ; adults, confirmed at Tarumi, Matsuyama City in June, 1953 by K. Sasaki; eggs, nymphs \& adults, confirmed at Hirao, Fukuoka City in March, 1959 by me.

Differs from arisana Kuwayama of Formosa in being smaller, in having the genal cones broader and not black at apex even in the over-wintered form, the female genitalia black with the dorsal valve upturned apically. (type-specimen of Psylla arisana $o$ in the Entomological Institute of Hokkaido University was examined.)

\section{Psylla pulchra (Zetterstedt)}

Chermes pulchra Zetterstedt, 1840, Ins. Lapp. : 309.

Psylla pineti Flor, 1861, Rhyn. Livl. 2: 471.

Psylla ornata Meyer-Diir, 1871, Mitt. Schw. Ent. Ges. 3 : 393.

Psylla similis Meyer-Diir, 1871, ibid. 3: 393.

Psyllanigrita Löw, Verh. zool.-bot. Ges. Wien $32: 244$.

Psylla sapporensis Kuwayama, 1908, Trans. Sapporo Nat. Hist. Soc. 2: 166. New Synonym.

Distribution: *Japan (Hokkaido, Honshu, Shikoku, Kyushu), Europe.

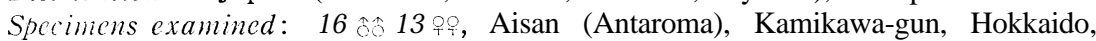
25. vii. 1962, Y. Miyatake leg. 1 , Nukabira, Tokachi, Hokkaido, 21-23. vii. 1959, K. Morimoto leg. 7 우, Kitami, Hokkaido, 10. vii. 1958, S. Miyamoto leg. 1 Suiren-numa, Aomori Pref., 11. vii. 1958, S. Miyamoto leg. 1今, Omogokei, 18. v

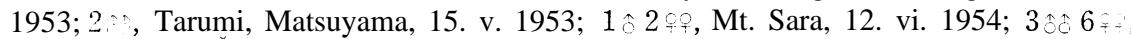
Sugitate, 18. vi. 1954 ; 5 ô 2 ợ , Mt. Sara, 11. v. 1954; Ehime Pref., K. Sasaki leg. $19 " 18 \subsetneq$, Mizunashi, nr. Fukuoka, 6. iii. 1960, Y. Miyatake leg.

Host plants: “ Inukori-yanagi ”- *Salix integra Thunb. [Salicaceaej ; nymphs, adults \& eggs, confirmed at Mizunashi, Fukuoka Pref, in March, 1960 by me. Salix sp. [Salicaceae]; nymphs \& adults, confirmed at Aisan, Hokkaido, in July, 1962 by me.

\section{Psylla elaeagni Kuwayama}

(Fig. 3, A)

Psyllaclacagni Kuwayama, 1908, Trans. Sapporo Nat. Hist. Soc. 2 :164. 
Distribution: Japan (Hokkaido, Honshu, Shikoku, Kyushu, Yakushima), *Korea.

Specimens examined: $1 \hat{\&}$, Mt. Dogo, Bingo, 4. vii. 1954, T. Ishihara leg. $3 \hat{\jmath} \hat{o}$ 6яㅇ, Todai-Kitazawa, Nagano Pref., 26. vii. 1959, Y. Miyatake leg. 1 ㅇ, Karuizawa, Shinano, 7-14. vii. 1959, K. Morimoto leg. 12 ô̂ 15 çํ, Yumoto, Nikko, 9. vii. 1961, K. Morimoto leg. 1 ? , Omogokei, Iyo, 18. v. 1953, K. Sasaki leg. 3 fo, Tarumi, Matsuyama, 29. iv. 1953, K. Sasaki leg. 5 ô 6 우, Shiomi-park, Matsuyama, 19. iv.

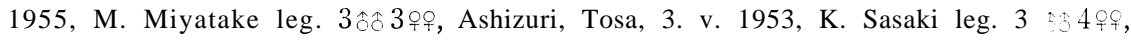
Anbô, Funayuki, Yakushima, 7. viii. 1929, H. Hori leg. 2 ̧̊̊, Kagoshima, 1-L vii. 1954, S. Miyamoto leg. 4. 1 \%t. Kaimon, Satsuma, 5. v. 1962, T. Hidaka leg. 1\%, Nagasakibana, Satsuma, 29. iii. 1957, M. Sonda leg. 1§, Cape Sata, Satsuma, 23. vi. 1957, T. Saigusa leg. 1\%1 Handa-Kôgen, Öita Pref., 20. vii. 1929, Esaki \& Fujino leg. 24 exs., Hikosan, Fukuoka Pref., 20. v. 1939, K. Yasumatsu leg. 2 领 2 우, Hakozaki, Fukuoka, 15. iv. 1955, Y. Miyatake leg. $1: 1$, 25-28. vii. 1958, Hirashima, Murakami \& Miyatake leg.; 1今, 26. vii. 1962, H. Hayashi \& M. Shiga leg.: Okinoshima, Chikuzen. 1仓, Izuhara-Sasutoge, Tsushima, 7. vi. 1941, T. Shirôzu leg. 1 ?, Suigen, Keiki-do, Korea, 5. ix. 1931, C. Takeya leg. Type-series cxamined: from Sapporo, Towada, Tateyama, Kamakura, Nikko,

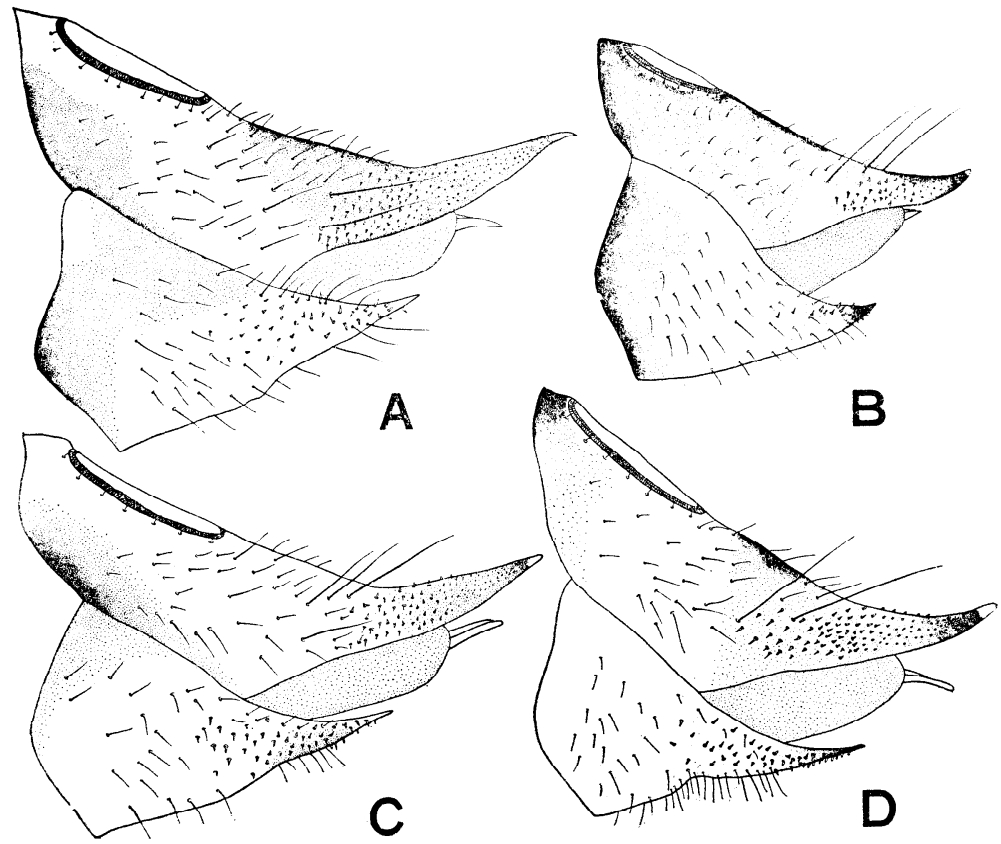

Fig. 3. Female genitalia of Psylla spp. feeding on Elaeagnus spp., lateral aspect.
A. Psylla elaeagni Kuwayama (on Elaeagnus umbellataThunb.).
B. Psylla elaeagnicola Y. Miyatake (on Elaeagnus umbellata Thunb.).
C. Psylla fulguralis Kuwayama (on Elaeagnus glabra Thunb.).
D. Psyllakiushuensis Kuwayama (on Elaeagnus pungens Thunb.). 
Takasago, Maiko, Hagi and Kagoshima (in the Entomological Institue of Hokkaido University).

Host plants: "Akigumi ”-Elaeagnus umbellata Thunb. [Elaeagnaceae]; nymphs \& adults, confirmed at Hakozaki, Fukuoka in April, 1958 by me; eggs \& nymphs, confirmed at Hakozaki, Fukuoka in April, 1959 by me. "Natsugumi "-Elaeagnus multiflora Thunb. [Elaeagnaceae] ; adults, confirmed at Yumoto, Nikko in July, 1961 by K. Morimoto; adults \& nymphs, cofirmed at Hakozaki, Fukuoka in May, 1958 by me.

\section{Psylla kiushuensis Kuwayama}

(Fig. 3, D)

Psyllakiushucensis Kuwayama, 1908, Trans. Sapporo Nat. Hist. Soc. 2: 174.

Distribution: Japan (*Honshu, *Shikoku, Kyushu), Formosa.

Specimens examined: Many examples from the following localities:

Fukuoka Pref. : Mt. Wakasugi (ii, Y. Miyatake; iv, K. Yano; vi, Y. Miyatake; xi, K. Morimoto); Hikosan (v, Y. Miyatake, M. Takahashi; vi, Y. Miyatake); Tsuda, Kokura (iii, Y. Miyatake) ; Mt. Tachibana (v, M. Sonda); Hriao (ii, v, Y. Miyatake) ; Inunaki (v, T. Saigusa); Mt. Kosho (v, S. Miyamoto); Mt. Hôman (v, vi, Y. Miyatake); Hakozaki, Fukuoka (iv, Y. Miyatake); Kashii, Fukuoka (iv, Y. Miyatake).

Ôita Pref. : Makiguchi (iii, Y. Miyatake); Tsukumi (iv, T. Tachikawa).

Saga Pref. : Mt. Kagami (v, M. T. Chûjo).

Kumamoto Pref. : Tatsuta-yama (iii, T. Kawarabata, Y. Miyatakej ; Amakusa (ix, Hori \& Chô); Kikuchi-suigen (v, Y. Miyatake).

Kagoshima Pref. : Yamakawa (iii, M. Sonda); Kagoshima city (iv, T. Saigusa); Cape Stata(v, I. Hiura).

Ehime Pref. : Sugitate (ii, iii, K. Sasaki); Mt. Ishizuchi (iv, K. Sasaki); Matsuyama (v, M. Miyatake) ; Syûso-gun (iv, K. Sasaki).

Kochi Pref. : Ashizuri (v, K. Sasaki); Shimizu-machi, Hada-gun (v, K. Sasaki).

Kagawa Pref. : Mt. Zoozu (v, Y. Miyatake); Zentsuji (i, Y. Miyatake).

Yamaguchi Pref. : Hagi (iv, S. Hashimoto).

Shiga Pref. : Mt. Ibuki (v, I. Hiura).

Mie Pref. : Osugidani, Suzuka (v, H. Ichihashi).

Type-series examined: $5 \hat{s}$ from Fukuoka in the Entomological Institute of Hokkaido University.

Host plants: "Nawashirogumi "-..*Elaeagnus pungens Thunb. [Elaeagnaceae] ; adults, nymphs \& eggs, confirmed at Mizunashi, nr. Fukuoka in February, 1958 and Makiguchi, Ôita Pref. in March, 1958 by me. "Marubagumi" or "Ôbagumi" -*Elaeagnus macrophylla Thunb. [Elaeagnaceae] ; adults, nymphs \& eggs, confirmed at Hakozaki, Fukuoka from February to April, 1959 by me.

\section{Psylla abieti Kuwayama}

Psylla abicti Kuwayama, 1908, Trans. Sapporo Nat. Hist. Soc. 2 : 175.

Psylla albopontis Kuwayama, 1908, Trans. Sapporo Nat. Hist. Soc. 2: 164. New Synonym. 
Distribution : Japan (Hokkaido, Shikoku, Honshu, *Kyushu).

Specimens examined: Many examples from the following localities :

Hokkaido : Abashiri (viii, T. Esaki); Aizankei (vii, Y. Miyatake); Mts. Daisetsu (vii, K. Sasaki, T. Kawarabata, Y. Miyatake); Meakandake (vii, S. Miyamoto, Y. Miyatake); Ashoro, Tokachi (vii, Y. Miyatake); Nukabira (vi, Tonosaki; vii, K. Yano; viii, Y. Miyatake); Shikotsu Lake (vi, H. Kuroko); Sounkyo (vii, K. Sasaki).

Aomori Pref. : Towada (xi, R. Matsuda); Takada-Ohdake (vii, T. Saigusa, Y. Miyatake); Sarukura, Mt. Hakkoda $(850 \mathrm{~m})$ (viii, K. Baba).

Akita Pref. : Hachimantai (vii, Y. Miyatake; viii, I. Hiura).

Nagano Pref. : Karuizawa (viii, S. Miyamoto).

Wakayama Pref. : Kôyasan (v, K. Noguchi).

Tottori Pref. : Daisen (v, S. Kimoto).

Ehime Pref. : Mt. Sara (vi, K. Sasaki); Mt. Ishizuchi (x, K. Sasaki).

Fukuoka Pref. : Hikosan (v, A. Habu; vi, K. Yasumatsu; vii, K. Morimoto, Y. Miyatake).

Type-series examined: from Sapporo, Jyozankei and Hagi in the Entomological Institute of Hokkaido University.

Host plants: “Ôshirabiso"-_Abies Mariesii Mast. [Pinaceae]; adults, confirmed at Hachimantai, Akita Pref. and Takada-Ohdake, Aomori Pref. in July, 1962 by me. "Akaezomatsu "-*Picea Glehnii Mast. [Pinaceae] ; adults, confirmed at Meakandake, Hokkaido in July, 1962 by me. "Ezomatsu"-Picea jezoensis Carr. [Pinaceae $\rceil$; adults, confirmed at Aizankei, Hokkaido in July, 1962 by me. Ahies spp. Pinaceae ; nymphs \& adults, Matsumura, 1917: 373.

Psylla albopontis described by Kuwayama (1908) is just one of the colour variations of this species (type-specimen $s$ of P.albopontis in the Entomological Institute of Hokkaido University was examined in 1962).

\section{Psylla albigena $Y$. Miyatake, sp. nov.}

(Fig. 4, A-D)

$\therefore \circ$. General colour red to reddish brown with white markings; antennae light orange with two apical segments black; genal cones wholly white or creamcoloured; eyes light to reddish brown ; ocelli orange to red ; anterior (near frontal ocellus) and posterior portion of vertex, antennal socket, posterior half of pronotum, lateral and posterior margins of praescutum, a few obscure stripes on scutum, lateral and posterior margins of scutellum, scutellum of metathorax, tergites of abdomen in the posterior two-thirds and sternites of abdomen along each segment white; posterior leg light brown, with black, apical spines at tibia and proximal segment of tarsus. Forewings hyaline, with veins yellowish brown, with a large, distinct black spot at tip of clavus (Fig. 4, A). Male genital segments brown, with forceps black apically; female genital segments brown to reddish brown.

Head conspicuously wider than thorax, vertical ; vertex rather small, distinctly shorter than half as long as wide at median line, with posterior margin strongly incised, discal (rather posterior) depressions very deep, swollen meso-anteriorly near frons, raised along median line, not pubescent; frons not visible; occiput not visible; genal cones (Fig. 4, B) broad, distinctly longer than vertex on median 
line, longer than wide, slightly divergent, blunt and broadly rounded or scarcely truncate obliquely at apex, strongly pubescent, nearly on same plane of vertex; eyes slightly recessive ; antennae moderately long, slender, 1.8 times as long as width of head, with two apical setae of the same length, relative lengths of the antennal segments as $3: 3: 12: 8: 8: 8: 7: 7: 3: 4$.

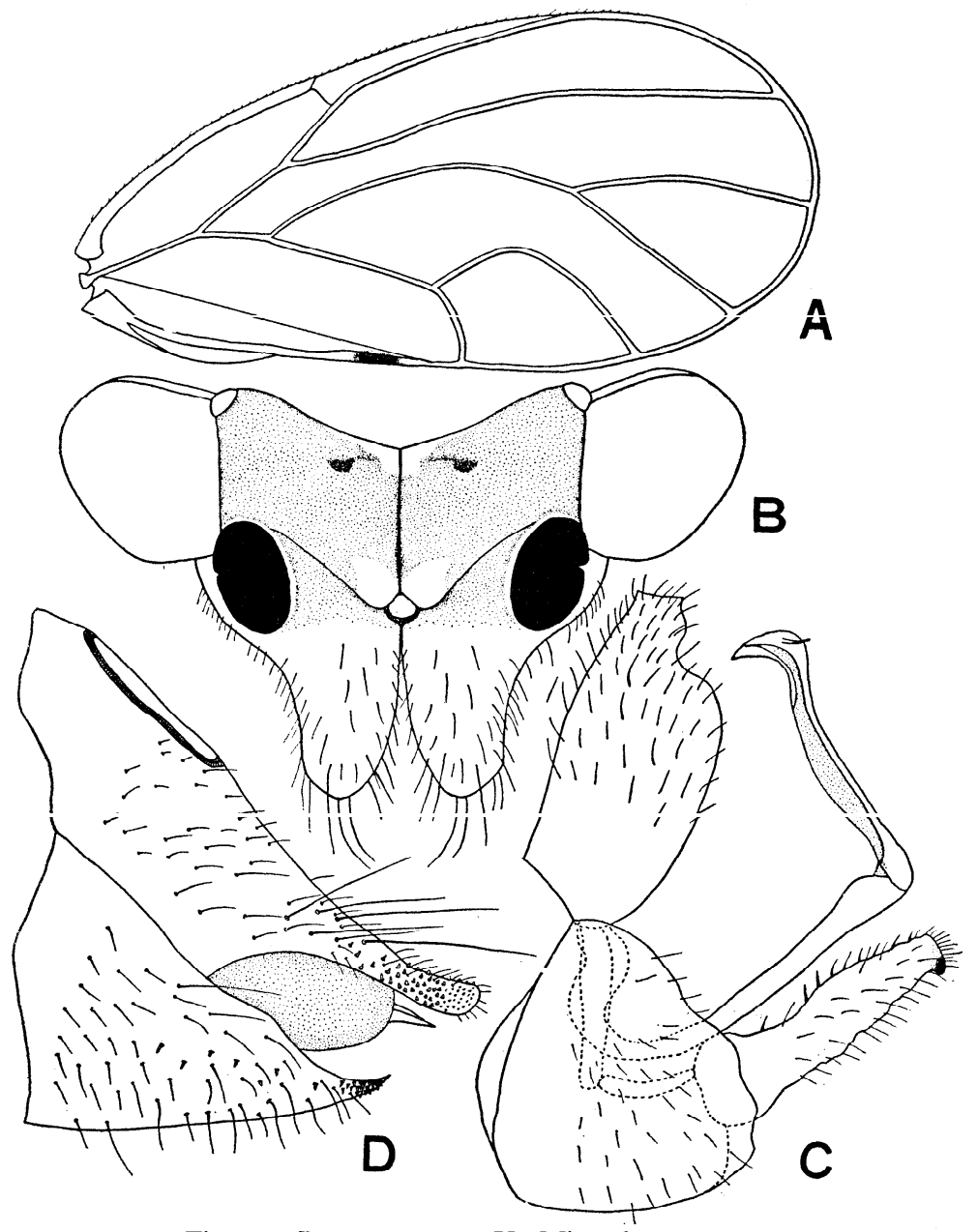

Fig. 4. Psylla albigena Y. Miyatake, sp. nov.

A. Forewing, $\bigcirc \quad$ B. Head (antennae excluded), frontal aspect, $\div$.

C. Male genitalia, lateral aspect. D. Female genitalia, lateral aspect.

Thorax robust and strongly arched, not pubescent; pronotum rather vertical, well arched, produced laterally, with lateral depressions deep; praescutum less than half as long as wide; scutellum somewhat hexagonal, half as long as wide, anterior angle. produced antero-laterally as a sharp arm. Legs stout, hairy; posterior femur swollen ; posterior tibia with a prominent basal spur, produced 
perpendicularly, with 2 outer and 3 inner apical spines; proximal segment of posterior tarsus with a pair of apical spines; meracanthus long, sharp, produced ventrad. Forewings long, very narrow basally and broad apically, with apex broadly rounded, over 2.1 times as long as wide, with anterior margin hairy almost to tip of Rs; pterostigma distinct, broad, over half as long as Rs, basally closed ; Rs sinuate, almost parallel with anterior margin, not upturned at tip; M strongly sinuate ; $\mathrm{M}_{1+2}$ and $\mathrm{Rs}$ not parallel to each other; $\mathrm{M}_{3+4}$ subparallel with $\mathrm{Cu}_{1}$; relative lengths of the veins $\mathrm{M}+\mathrm{Cu}, \mathrm{Cu}, \mathrm{Cu}_{2}, \mathrm{M}_{1+2}$ and $\mathrm{M}_{3+4}$ as $13: 31: 13$ : 36 : 32; first marginal (cubital) cell wider than high, about $37 \times 23$, somewhat quadrilateral. Abdomen (excl. genital segments) long, almost as long as width of head, broad anteriorly and narrow posteriorly, without pubescence dorsally, with sparse pubescence ventrally.

Male genital segments (Fig. 4, C) small, 0.3 times as long as the rest of abdomen, pubescent; proctiger in lateral aspect short, broad, slightly longer than forceps, slightly curved caudad and truncate apically ; forceps in lateral aspect slender, 0.8 times as long as proctiger, narrowed basally and tapering towards blunt apex, with posterior margin almost straight, in caudal aspect stout, strongly arched, touched and acute apically, with inner surface with numerous, retrorse, setae; aedeagus long, with first segment hook-shaped and 1.5 times as long as second segment, with apical portion of second segment transformed as --shaped; subgenital plate small, as high as proctiger in lateral view, with dorsal margin rather straight in the anterior two-thirds and descending in the posterior one-third, with anterior and posterior margins rounded. Female genital segments (Fig. 4, D) nearly half as long as the rest of abdomen, pubescent (especially in the posterior half); dorsal valve distinctly longer than ventral in lateral view, broad basally and narrow in the apical half, truncate apically, with dorsal margin slightly upcurved apically; anus in larger diameter 0.4 times as long as dorsal valve; inner valve long, scarcely shorter than dorsal; ventral valve subtriangular, very high at base, acute and strongly upturned apically.

Length of body $2.0-2.3 \mathrm{~mm}$, $\$ 2.2-3.0 \mathrm{~mm}$ (to tip of folded wings $\$ 3.7-4.1$ $\mathrm{mm}$, o $4.3-4.4 \mathrm{~mm}$ ); length of forewing $\$ 3.1-3.4 \mathrm{~mm}$, $93.6-3.7 \mathrm{~mm}$; length of antenna $1.3-1.4 \mathrm{~mm}, \stackrel{\circ}{\circ} 1.4 \mathrm{~mm}$.

Distribu tion: Japan (Honshu).

Holotypc (९): Karuizawa, Shinano (Nagano Pref.), Honshu, 7-1t. vii. 1959, K. Morimoto leg.

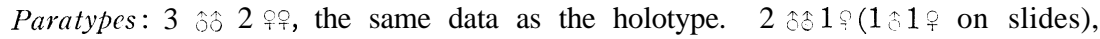
Karuizawa, Shinano (Nagano Pref.), Honshu, 5. viii. 1959, S. Miyamoto leg. 1 , Karuizawa, Nagano Pref., Honshu, 3-8. viii. 1959, H. Kamiya leg. 1s, Hakone, Kanagawa Pref., Honshu, 26. vi. 1961, (on Rhododendron sp.), K. Morimoto leg.

Host plant: Rhododendron sp. (?)

Differs from fatsiae Jensen in coloration, in having the female genitalia longer and the dorsal valve rather truncate instead of rounded apex, the genal cones broader, the proctiger of the male genitalia much more stout, and in having Rs not upturned at tip (more or less upturned in fatsiae Jensen). Differs from toroenensis Kuwayama in coloration and in having the genal cones distinctly longer than the vertex (distinctly shorter in toroenensis Kuw.). Differs from coccinea Kuwayama in being larger, in having the genal cones' wholly white and the discal depressions strongly deep, in having the forceps of the male genitalia 
more slender and tapering, and the dorsal valve of the female genitalia horizontal and less stout in the apical third (rather descending and stout in coccinea), though resembles in coloration.

\section{Psylla fatsiae Jensen}

(Fig. 5, A-D)

Psylla fatsiae Jensen, 1957, Wasmann J. Biol., San Francisco 15: 21.

Distribution: *Japan (Hokkaido, Shikoku, Kyushu), California.
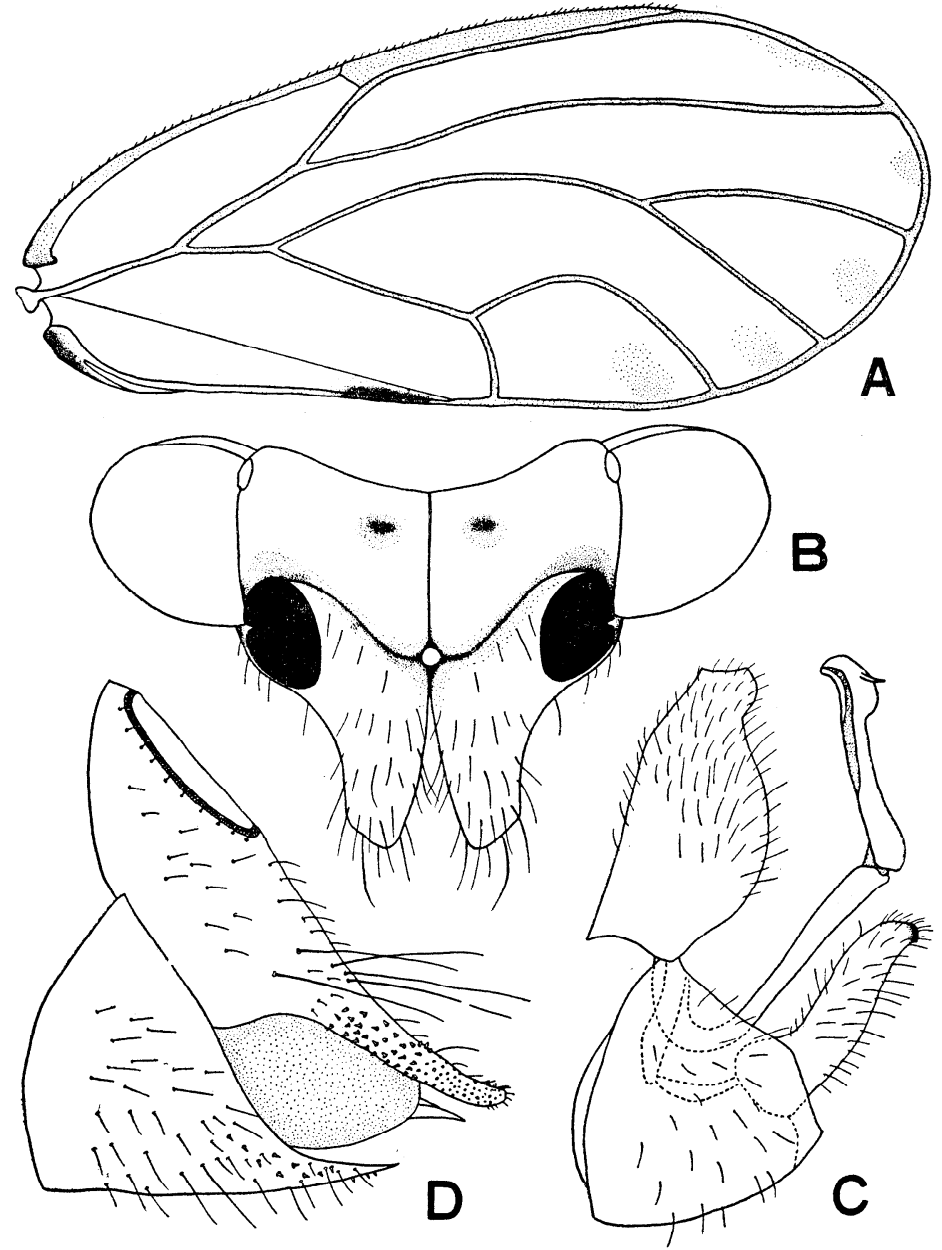

Fig. 5. Psylla fatsiae Jensen.
A. Forewing, 3 .
B. Head (antennae excluded), frontal aspect, $A$.

C. Male genitalia, lateral aspect.

D. Female genitalia, lateral aspect, 
Specimens examined: 1ํ, Hikosan, Fukuoka Pref., 4. viii. 1951, K. Yasumatsu

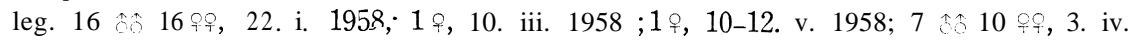

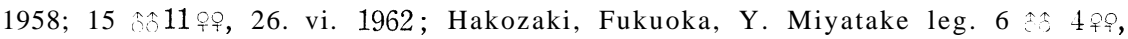
Hirao, Fukuoka, 14. ii. 1958, Y. Miyatake leg. 1s, Mt. Ariake, Tsushima, 12. vii. 1960, H. Kamiya leg. 4 2 $2 \circ$, Miyazaki, 27. v. 1951, S. Miyamoto leg. 1 , Cape Sata, Satsuma, 29. v. 1953, I. Hiura leg. 3 ㅅํㅇ 3 우, Uwajima, Iyo, 30. iv. 1956, T. Yano leg. 1ㅇ, Minatoyama, 3. v. 1953, M. Miyatake leg. 1 ? , Sugitate, nr. Matsuyama, 1. iv. 1958, K. Sasaki leg. 3 po, Nukabira, Tokachi, Hokkaido, 17. v. 1959, M. Tonosaki leg.

Host plants: "Yatsude"-Fatsia japonica Decne et Planch. [Araliaceae]; adults, nymphs \& eggs, confirmed at Hakozaki, Fukuoka in January and April, 1958 by me; adults, confirmed in Uwajima, Iyo in May, 1956 by T. Yano. "Taranoki"-*Aralia clata Seem. [Araliaceae]; alults, confirmed at Nukabira, Hokkaido in May, 1959 by M. Tonosaki.

\section{Psylla toroenensis Kuwa yama}

Psyllatoroenensis Kuwayama, 1903, Trans. Sapporo Nat. Hist. Soc. 2 : 172.

Distribution: *Japan (Honshu, Shikoku, Kyushu), Formosa.

Specimensexamined: 3 $16 \% \circ$, Mt. Sefuri, 22. ii. 1958 ; 9 so 15 cợ, Tsuda, Kokura, 22. iii. 1958; 2 워, Mizunashi, 9. ii. 1958; 5 ŝㅇำ 14 우, Mt. Wakasugi, 16. ii. 1958; 9 , Hirao, Fukuoka, 14. ii. 1958: Fukuoka Pref., Y. Miyatake leg. 2 领 $8 \ldots$ Kôrasan, nr. Kurume, 21. vi. 1952, I. Hiura leg. 3 \%o, Mt. Kujuh, Ôita Pref., 16. iii. 1958, Y. M'iyatake leg. $1 \lesssim 1$, Tatsutayama, Kumamoto Pref., 23. iii. 1960, Y. Miyatake leg. 1 今 2 , Omogokei,3-4. v. 1958, Y. Miyatake leg. ; 1 , Sugitate, 16. i. 1953, F. Takechi leg.; $191 \%$ Higashino, Matsuyama, 9. i. 1953, T. Funabiki leg.; Ehime Pref. 1, Syumura, Syuso-gun, 7. iv. 1953; 4 $\hat{\delta} 4$ fo, Sugitate, nr.

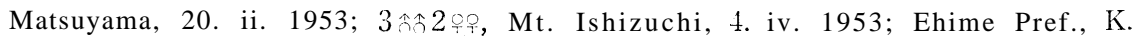
Sasaki leg. 1\%, Kure, Hiroshima Pref., 23. xii. 1935, T. Ishihara leg.

Type-specimenexamined: one female from Toroen, Formosa in the Entomological Institute of Hokkaido University (broken and without both forewings and antennae).

Host plant: “ Kizuta "-*Hedera rhombea Bean [Araliaceae]; adults \& eggs, confirmed at Hakozaki, Fukuoka in February, 1959 by me; nymphs \& adults, confirmed at Mt. Sefuri, nr. Fukuoka in February, 1958 and Tsuda, Kokura in March, 1958 by me.

\section{Psylla carpinicola Crawford}

Psylla carpinicola Crawford, 1914, U. S. Nat. Mus. Bull. 85: 151. Psyllacarpini Fitch (nec Förster, 1848), 1851, 4th Rept. N. Y. St. Mus. :64. Psyllacarpina Smith, 1910, Ins. N. J. : 109.

Psylla cephalica Crawford, 1914, U. S. Nat. Mus. Bull. 85: 138,151.

Psyllia carpinicola Crawford: Van Duzee, 1917, Cat. Hemip. N. Am. : 809. Psyllia cephalica Crawford : Van Duzee, 1917, ibid. : 809.

Distribution: *Japan (Honshu), N. America.

Specimens examined: $2556 \% 9,7-14$. vii. 1959, K. Morimoto leg.; 2 5, 5. viii. 1959, S. Miyamoto leg.; Karuizawa, Nagano Pref. 
Host plant: Carpinus caroliniana [Betulaceae] ; Tuthill, 1943: 469 (in N. America).

\section{Psylla hartigii Flor}

Psylla hartigii Flor, 1861, Rhynch. Liv. 2 : 450, 469.

Psylla sylvicola Lethierry, 1874, Cat. Hémip. Dept. Nord. : 90.

Psylla hartigi Flor : Aulmann, 1913, Psyll. Cat. : 16.

Distribution: *Japan (Hokkaido, Honshu), Europe, Russia, N. America.

Spccimens examined : 1 , Jozankei, 16. vii. 1953, K. Sasaki leg. 1 , Karuizawa, Shinano, 7-14. vii. 1959, K. Morimoto leg. 1ㅇ, 15-17. vii. 1962, K. Hara leg.; 1 , 31. vii. 1962, S. Miyamoto leg.; Mt. Nyuhgasa, Nagano Pref.

Host plants: Betulaalba [Betulaceae]; Sulc, 1911: 29 (in Europe). Betula populifolia [Betulaceae] ; Crawford, 1914 : 146 (in N. America).

\section{Psylla coccinea Kuwayama}

Psylla coccinea Kuwayama, 1908, Trans. Sapporo Nat. Hist. Soc. 2: 171.

Psylla akebiae (Shinji, 1942), Ins. World 46: 354 (Aphalara). Mew Synonym.

Distribution: Japan (Hokkaido, Honshu, Shikoku, Kyushu), Formosa.

Type-seriesexamined: from Hakodate, Kamakura, Hagi, Takasago and Kagoshima in the Entomological Institute of Hokkaido University.

Specimens examined: Numerous examples from the following localities :

Aomori Pref. : Mt. Iwaki (viii, Y. Murakami).

Akita Pref.: Yajima (vii, I. Hiura); Hachimantai (vii, Y. Miyatake).

Nagano Pref.: Onnazawa (vi, K. Oshima; viii, Y. Miyatake); Komagadake (vii,

S. Miyamoto); Mt. Nyuhgasa (vii, S. Miyamoto) ; Minami-minowa (viii,

Y. Miyatake); Karuizawa (vii, K. Morimoto, H. Kamiya).

Yamanashi Pref. : Kitazawa (vii, Y. Miyatake).

Kanagawa Pref. : Hakone (vi, K. Morimoto).

Mie Pref. : Meigurodake (vi, C. Ôkawa).

Ôsaka Pref. : Mt. Iwawaki (v, I. Hiura).

Kagawa Pref. : Mt. Zoozu (v, Y. Miyatake).

Kochi Pref. : Kuroson (iv, T. Hidaka ; vii, T. Edashige); Ashizuri (v, K. Sasaki) ; Murotozaki (vii, S. Miyamoto).

Tokushi ma Pref.: Minaminoma (vii, S. Miyamoto).

Fukuoka Pref. : Hikosan (v, Esaki, Yasumatsu \& Hirashima; vi, K. Morimoto; viii, Y. Miyatake); Inunaki-tôge (vii, Y. Miyatake); Mt. Wakasugi (v, Hori, Hashimoto \& Cho) ; Kanayama (vi, Y. Miyatake); Mizunashi (v, R. Matsuda); Mt. Tachibana (v, M. Sonda, Y. Miyatake).

Nagasaki Pref. : Izuhara, Tsushima (v, Esaki \& Fujino; vi, T. Shirôzu); Mt. Ariake, Tsushima (v, H. Kamiya); Fukue, Goto Is. (ix, S. Miyamoto).

Saga Pref.: Ukidake (v, T. Hidaka).

Ôita Pref. : Mt. Sobo (vi, Hori, Fujino \& Cho).

Kumamoto Pref. : Kikuchi-suigen (v, Y. Miyatake).

Kagoshima Pref. : Yamakawa (v, I. Hiura; vii, Y. Miyatake)

Host plants: "Akebi "-Akebia quinata Decne.[Lardizabalaceae-; adults \& nymphs, confirmed at Onnazawa, Nagano Pref. in August, 1962 by me; adults, 
confirmed at Ashizuri, Tosa in May, 1953 by K. Sasaki. "Mube"-*Stauntonia hexaphylla Decne. [Lardizabalaceae]; adults \& nymphs, confirmed at Mt. Tachibana, Fukuoka in May, 1958 by me. "Mitsuba-akebi "-_Akebiatrifoliata Koidz. [Lardizabalaceae]; adults, nymphs \& eggs, confirmed at Mt. Tachibana, Fukuoka in May, 1959 and Kikuchi-suigen, Kumamoto Pref. in May, 1962 by me.

The descriptions of $P$. akebiae Shinji, 1942 are applicable to characters of the newly-emerged form of this species.

\section{Psylla hederae Y. Miyatake, sp. nov.}

(Fig. 6, A-D)

$\therefore$ : General colour yellowish brown, but greenish in the newly-emerged form; abdomen more or less greenish and thorax brownish; two apical segments of antennae and apical spines of posterior tibia and tarsus black; eyes reddish to dark brown; ocelli and vertex, especially around lateral ocelli, reddish. Forewings flavous, with veins yellowish brown.

Head wider than thorax, deflexed; vertex longer than half as long as wide, with posterior margin slightly incised, raised along median line, with discal depression deep, sparsely pubescent near antennal socket; genal cones (Fig. 6, B) shorter than vertex, stout, nearly as long as wide at base, broadly rounded apically, moderately divergent, pubescent throughout; occiput visible only laterally in caudal view; frons not visible; antennae slender, with two apical setae of the same length, relative lengths of the antennal segments as $3: 3: 10: 6: 6: 6$ : $6: 4: 2: 3$

Thorax robust, not pubescent, rugose as finely as vertex; pronotum nearly vertical, convex anteriorly, longer than half as long as vertex in frontal view, with posterior margin straight; praescutum half as long as wide; scutum short, 0.4 times as long as wide; scutellum large, continuous from scutum, subtrapezoidal, less than half as long as wide. Legs massive, hairy; all femora swollen equally; posterior tibia with a short but prominent basal spur, with 2 outer and 3 inner apical spines; proximal segment of posterior tarsus with a pair of apical spines ; meracanthus comparatively long, as long as basal segment of antenna, pro jected ventro-caudad, acute apically. Forewings (Fig. 6, A) short and broad, somewhat ovate, twice as long as wide, broadly rounded at apex with anterior margin pubescent to tip of pterostigma; pterostigma broad and short, nearly half as long as Rs; Rs sinuate, slightly upcurved at apex; Cur and $\mathrm{Cu}_{2}$ subparallel to each other so that cubital (first marginal) cell somewhat parallelogramy ; medial (second marginal) cell longer than cubital, relative lengths of the veins $\mathrm{M}+\mathrm{Cu}, \mathrm{Cu}, \mathrm{CuQ}, \mathrm{M}_{1+2}$ and $\mathrm{M}_{3+4}$ as $1: 2.2: 1.1: 2.5: 2.3$. Abdomen (excl. genital segments) almost as long as width of head; tergites with microtrichiae along each segment; sternites sparsely pubescent.

Male genital segments (Fig. 6, C) small, 0.3 times as long as the rest of abdomen, densely pubescent; proctiger nearly as long as forceps, broad basally, narrowed and slightly curved caudad apically ; forceps (exposed portion) in lateral aspect slightly narrow at base, almost evenly tapered to subacuute tip, curved mesad and caudad, in caudal view slender, arched to tips which are acute and touched, with inner face with long, retrorse hairs; aedeagus typical, with first segment 1.5 times as long as second, with second segment transformed as somewhat beak- 
shaped apically ; subgenital plate subtriangular, as high as proctiger. Female genital segments (Fig. 6, D) rather long, half as long as the rest of abdomen, broad basally, with dorsal valve descending; dorsal valve distinctly longer than ventral, with dorsal margin sinuate and upturned at apex, with long hairs, with apical one-third attenuate and granulated, slightly thickened and truncate at apex; anus in larger diameter nearly half as long as dorsal margin of dorsal valve; inner valve shorter than dorsal and longer than ventral; ventral valve narrow and granulated on the surface apically, with apex acute and strongly upturned.
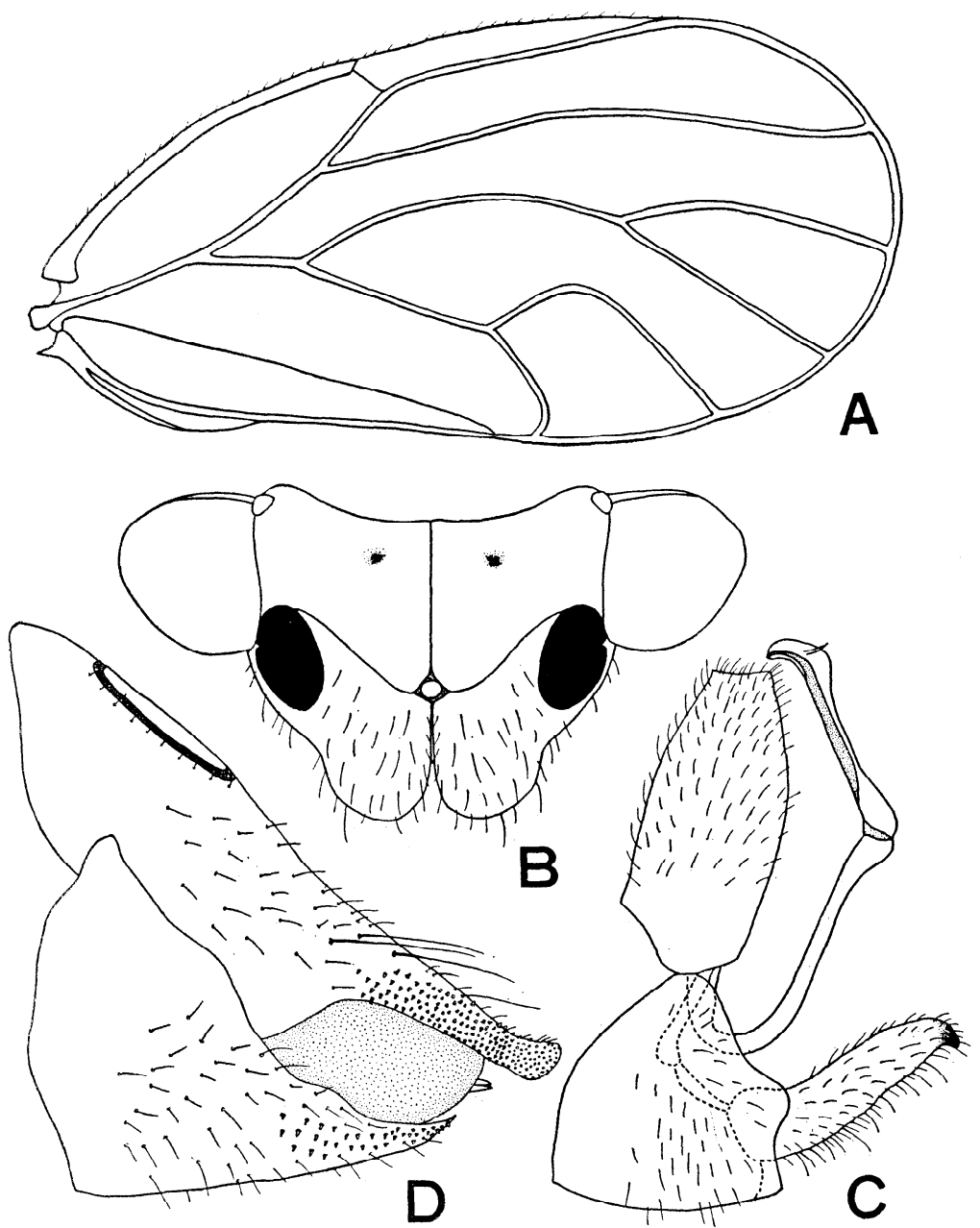

Fig. 6. Psyllahederae Y. Miyatake, sp. nov.
A. Forewing, $\hat{0}$.
B. Head (antennae excluded), frontal aspect,

C. Male genitalia, lateral aspect.

D. Female genitalia, lateral aspect. 
Length of body $31.7-1.9 \mathrm{~mm}$, ㅇ $2.0-2.4 \mathrm{~mm}$ (to tip of folded wings $\hat{2} 2.6-2.8$ $\mathrm{mm}$, $2.8-3.0 \mathrm{~mm}$ ) ; length of forewing $2.1-2.3 \mathrm{~mm}$, $2.3-2.5 \mathrm{~mm}$; length of antenna $\hat{o} 1.1-1.2 \mathrm{~mm}$, ํ.1.1- $1.2 \mathrm{~mm}$.

Distribution: Japan (Kyushu, Shikoku).

Holotype (̊): Tajima, Fukuoka City, Kyushu, 29. v. 1958, Y. Miyatake leg. (on Hedera rhombea Bean).

Paratypes: 15 of 22 우, the same data as the holotype on the same host.

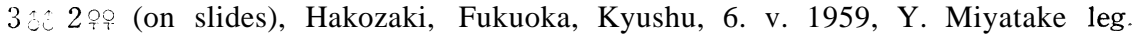
4 ڤ̊ 4 ợ, Kamisaka, Tsushima, Nagasaki Pref., Kyushu, 17. v. 1961, H. Kamiya leg. 1^, Tsutsu, Tsushima, Nagasaki Pref., Kyushu, 25. v. 1957, K. Baba leg.

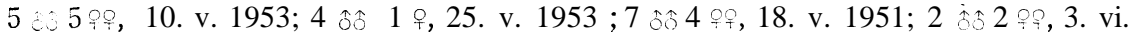
1953 ; Sugitate, nr. Matsuyama, Ehime Pref., Shikoku, K. Sasaki leg. 191 ?, Mt. Zoozu, Sanuki (Kagawa Pref.), Shikoku, 1-2. v. 1958, Y. Miyatake leg.

Host plant: "Kizuta "-Hedera rhombea Bean [ Araliaceae] ; eggs, nymphs and adults, confirmed at Hakozaki, Fukuoka City in May, 1958 and Mt. Wakasugi, near Fukuoka in May, 1959 by me; adults, confirmed at Sugitate, nr. Matsuyama in May, 1953 by K. Sasaki.

Differs from horii Kuwayama of Yakushima in having the genal cones much more robust and short, as long as wide, half as long as the vertex, less tapering (slender, nearly as long as the vertex or slightly longer in horii Kuw.), and in having the forceps of the male genitalia slender and almost as long as the proctiger (stout and distinctly shorter than the proctiger in horii Kuw.) and the dorsal valve of the female genitalia more attenuate and apically swollen so that the dorsal margin slightly upcurved as figured (compared with the type-series of Psyllahorii Kuwayama in the collection of the Entomological Laboratory, Kyushu University). Differs from toroenensis Kuwayama on the same host plant, in being smaller, in having the forewings flavous rather than transparent and without dark spot at apex of clavus (prominent in toroenensis Kuw.), just about twice as long as wide (2.3 times in toroenensis Kuw.), the cubital (first marginal) cell of forewing almost as wide as high, parallelogramy (much wider than high, about $27 \times 16$, not parallelogramy in toroenensis Kuw.), the antennae shorter, about 1.3 times as long as width of head (1.6 times in toroenensis Kuw.), although resembles in the genital characters.

\section{Psylla moiwasana Kuwayama}

Psyllamoiwasana Kuwayama, 1908, Trans. Sapporo Nat. Hist. Soc. 2: 175.

Distribution: Japan (Hokkaido).

Type-series examined: $2 \%$, Moiwa, Sapporo, 28. v., S. Matsumura leg. in the Entomological Institute of Hokkaido University.

Host plant: unknown.

\section{Psylla ambigua Förster}

Psylla ambigua Förster, 1848, Verh. Nat. Ver. Preuss. Rheinl. 3: 74.

Psylla insignis Förster, 1848, ibid. 3: 74.

Psylla melina Flor, 1861, Rhynch. Livl. II : 477.

Psylla stcnolabis F. Löw, 1876, Pet. Nouv. Ent. 2: 64. 
Psylla annellata (Thomson, 1877), Opusc. Ent. Fasc. 8: 835 (Chermes).

Distribution: Japan (Hokkaido, *Honshu), Siberia, Europe.

Spccimcns cxamincd: 1 ?, Aizankei, Kamikawa-gun, Hokkaido, 24. vii. 1962, Y. Miyatake leg. 152 , Ashoro, Tokachi, 24-31. vii. 1959, K. Morimoto leg. 1. Mt. Daisetsu, Hokkaido, 18. vii. 1953, K. Sasaki leg. 2, *, 30. vii. 1962, Y. Miyatake leg.; 1 ; ; vii. 1958, S. Miyamoto leg. ; Meakandake, Akan-gun, Hokkaido. 1 ;, Moiwa, Sapporo, Hokkaido, 17. vii. 1959, K. Morimoto leg. 1 ;, Nukabira, Tokachi, Hokkaido, 24-31. vii. 1959, K. Morimoto leg. 19, Sapporo, Hokkaido, vi. 1903, S. Matsumura Y. leg. 2 ?o, Takada-Ohdake, Aomori Pref., 14. vii. 1962, Y. Miyatake leg. 1؟, Shiroyama, Iwakuni, 1. viii. 1.950, S. Miyamoto leg.

Host plants: Salix alba L., S. aurita L., S. glauca, S. caprea L., S. viminalis L., S. incana Schrank [Salicaceae]; Vondráček, 1957: 238 (in Europe).
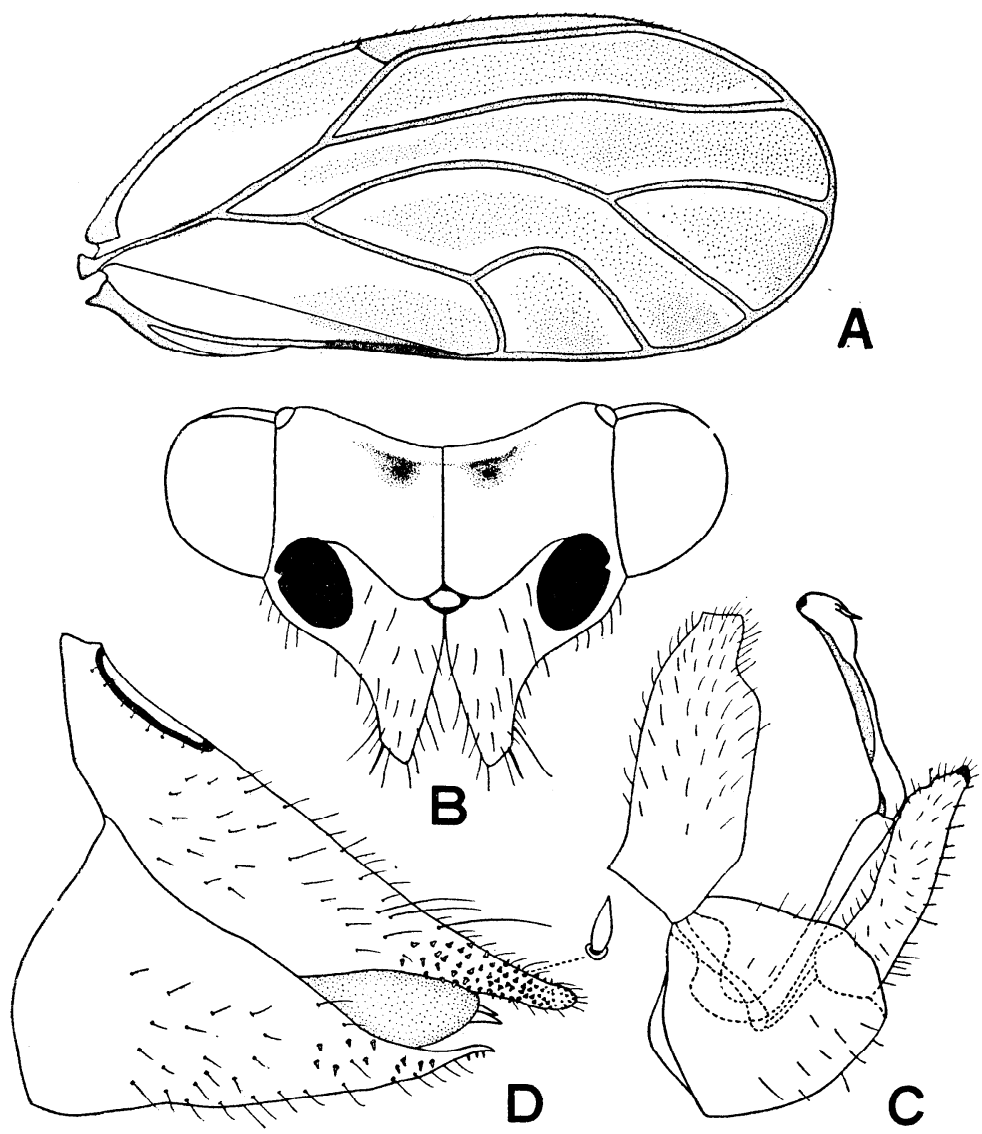

Fig. 7. Psylla ledi Flor.

A. Forewing, $\quad$ B. Head (antennae excluded), frontal aspect,
C. Male genitalia, lateral aspect.
D. Female genitalia, lateral aspect. 


\section{Psylla ledi Flor}

(Fig. 7, A-D)

Psylla ledi Flor, 1861, Rhynch. Livl. 2: 473.

Chermes lutea Thomson, 1878, Opusc. ent. 8: 833.

Distribution : Japan (Hokkaido), Europe, Russia.

Specimens examined : 21 11 ○o , Kawayu, Kushiro, 17. vii. 1955, K. Yasumatsu leg. 3 o 6 , 5. vii. 1958, S. Miyamoto leg.; 4 ô $6 \%$, 7. vii. 1958, M. Miyatake leg.; 3 क् , 5. vii. 1962, H. Kuroko leg.; 29 ôे 20 우, 30. vii. 1962, Y. Miyatake leg.;

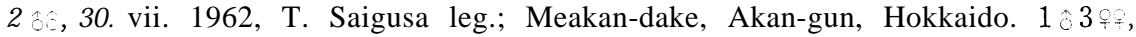
T. Kawarabata leg. ; 17 解 23 우유, K, Yano leg.; 3. viii. 1959, Kawayu-Yuohzan, Akan-gun, Hokkaido. 1 , Kawayu, Kitami Prov., 28. vi. 1961, S. Kuwayama leg. 5 ô 11 우, Aizankei, Kamikawa-gun, 18-24. vii. 1962, Y. Miyatake leg. 1 , Yukomanbetsu, 2. vii. 1958, M. Miyatake leg.; 2 ồ 4 ợ?, 22-24. vii. 1959, T. Kawarabata leg. \&9 18 18 우, 18. vii. 1953, K. Sasaki leg., Mt. Daisetsu; Kamikawagun, Hokkaido. 19, Kurodake, Mts. Daisetsu, 21. vii. 1962, Y. Miyatake leg.

Host plant: "Ezo-isotsutsu ji "-*Ledum palustre Linn. var. nipponicum Nakai [Ericaceae] ; adults. \& nymphs, confirmed at Utsukushigahara, Mts. Daisetsu, Hokkaido in July, 1962 by me and Yuohzan in August, 1959 by K. Yano: adults confirmed at Meakandake, Hokkaido in July, 1962 by me.

\section{Psylla mali (Schmidberger)}

Chermes mali Schmidberger, 1836, Beitr. z. Nat. Schädl. Ins. 4: 186.

Psylla mali Förster, 1848, Verh. natur. Ver. preuss. Rhein. $3: 72$.

Psylla pomi Förster, 1848, Verh. natur. Ver. preuss. Rhein. 3: 72.

Psylla crataegicola Forster, 1848, ibid. $3: 72$.

Psylla aeruginosa Forster, 1848, ibid. $3: 97$.

Psylla occulta Fdrster, 1848, ibid. 3 : 98.

Psylla dubia Förster, 1848, ibid. $3: 73$.

Psylla rubida Meyer-Dür, 1872, Mitt. Sch. Ent. Ges. 3: 398.

Psyllaclaripennis Meyer-Dür, 1872, ibid. $3: 400$.

Psyllaviridissima Scott, 1876, Trans. Ent. Soc. London 1876: 543.

Psyllia mali: Brittain, 1.919, Agri. Gaz. Can. 6: 823-827, figs.

Distribution: Japan (Hokkaido, Honshu), Europe, N. America.

Specimens examined : 3 , Jozankei, 16. vii. 1953; 3 的 3 , Sounkyo, 17. vii $1953 ; 29$; 26 , Sapporo, 14. vii. $1953 ; 4$ o 2 , Mt. Daisetsu, Kamikawa-gun, 18. vii. 1953 ; K. Sasaki leg. 1 , 14. vii. 1953, T. Ishihara leg. $; 1 \_1$, 12. viii. 1962, Y. Miyatake leg.; Sapporo, Hokkaido. 21 21 17-18. vii. 1962, Y. Miyatake leg. ; 2 1 25. vii. 1962, T. Saigusa leg. ; Aizankei, Kamikawa-gun, Hokkaido, 1 \&, Aisan (Antaroma), 25. vii. $1962 ; 16$ ô 8 ? Mts. Daisetsu, 21-23. vii. 1962; Kamikawa-gun, Hokkaido, Y. Miyatake leg. (The Japaneses specimens were compared with the European ones with Dr. Eastop's favour of the British Museum.)

Host plant: "Ringo"-Malus pumila Mill. var. dulcissima Koidz. Rosaceae nymphs \& adults, Matsumura, 1917: 373. 


\section{Psylla peregrina Förster}

Psylla peregrina Fiirster, 1848, Verh. naturw. Ver. preuss. Rhein. 3: 74.

Psylla carpini Förster (nec Fitch, 1851), 1848, ibid. 3: 72.

Psylla crataegicola Flor, 1861, (nec Förster, 1848), Rhynch. Livl. 2: 474.

Distribution: Japan (Hokkaido, Honshu), Europe.

Specimens examined : 1 ^ 2 우, Mt. Daisetsu, 18. vii. 1953, K. Sasaki leg. 14 fo, Takada-Ohdake, Aomori Pref., 14. vii. 1962, Y. Miyatake leg. 2 , 1 , Hachimantai, Akita Pref., 12. vii. 1962, Y. Miyatake leg.

Host plants: Crataegusoxycantha L. [Rosaceae] ; Aulmann, 1913: 22 (in Europe). Cratacgusmonogyna Jacq. [Rosaceae] ; Vondrácek,1957: 253 (in Europe).

\section{Psylla multipunctata Y. Miyatake, sp. nov.}

(Fig. 8, A-E)

. - : General colour yellowish brown; antennae brown, with two apical segments and with tips of remaining ones black; eyes light to dark brown; ocelli yellow; vertex and thorax usually with dark brown area; genal cones darker laterally; forewings (Fig. 8, A) subhyaline, maculated, covered with brown dots on veins and membrane irregularly, becoming more dense apically ; veins whitish brown, lighter apically; abdomen greenish brown, with the apical half of female genital segments brown.

Head nearly as wide as thorax; vertex slightly longer than half as long as broad, nearly plane, discal impressions shallow, with posterior margin incised ; occiput well covered; genal cones (Fig. 8, B) exceedingly short, half as long as vertex, almost parallel to each other, each cone cylindrical, broadly rounded or even truncate horizontally at apex, not depressed below plane of vertex, very sparsely pubescent, with a pair of long hairs at apex; frons reduced, not visible; antennae slender, long, nearly half as long as forewing, with two long apical setae of the same length.

Thorax broad, smooth, without conspicuous pubescence ; pronotum anteriorly arched, with a little pubescence laterally ; scutum robust, short, about $10 \times 23$; scutellum rectangular. Legs rather stout; posterior tibia without a basal spur, with 3 outer and 1 inner black apical spines, proximal segment of posterior tarsus with a pair of black spines at apex; meracanthus (Fig. 8, E) long, acute apically. Forewings (Fig. 8, A) long, about two and half times as long as broad, narrow basally, broadly rounded apically, with anterior margin pubescent; pterostigma distinct, but short; Rs distinctly upturned; $\mathrm{M}_{1+2}$ and $\mathrm{M}_{3+4}$ very short; first marginal (cubital) cell exceedingly large, much larger than second, somewhat parallelogramy ; second marginal (medial) cell almost equilateral triangular ; relative lengths of the veins $\mathrm{M}-\mathrm{t} \mathrm{CU}, \mathrm{CU}, \mathrm{Cu}_{2}, \mathrm{M}_{1+2}, \mathrm{M}_{3+4}$ as $8: 15: 8: 15: 13$. Abdomen short.

Male genital segments (Fig. 8, C) in profile moderately large; proctiger slender, one and half as long as forceps, densely hairy, with anterior margin rather straight, narrowed apically ; forceps slender, somewhat sickle-shaped, tapering to a somewhat acute apex, with apex slightly curved anteriorly in later-a.1 view, with posterior margin densely pubescent, caudal aspect of forceps slender, gently curved mesad, inner face with numerous small setae; subgenital 
plate small, as high as proctiger, with long pubescence, with anterior margin well covered with terminal abdominal segment. Female genital segments (Fig. 8 , D), in lateral aspect, moderately long, nearly as long as the rest of abdomen; dorsal valve much longer than ventral, tapering to blunt apex, with a number of long hairs dorsally; ventral valve in lateral aspect short, broad, subtriangular, hairy in ,the basal half.

Length of body $\$ 1.2-1.3 \mathrm{~mm}$, $1.7-1.8 \mathrm{~mm}$; length of forewing $\$ 1.8-1.9 \mathrm{~mm}$, $\div 2.0-2.1 \mathrm{~mm}$; length of antenna $\$ 0.8-0.9 \mathrm{~mm}$, क $0.8 \mathrm{~mm}$.

Distribution: Japan (Kyushu).

Holotype (今): Mt. Hôman, Chikuzen (Fukuoka Pref.), Kyushu, 19. vi. 1962, Y. Miyatake leg.
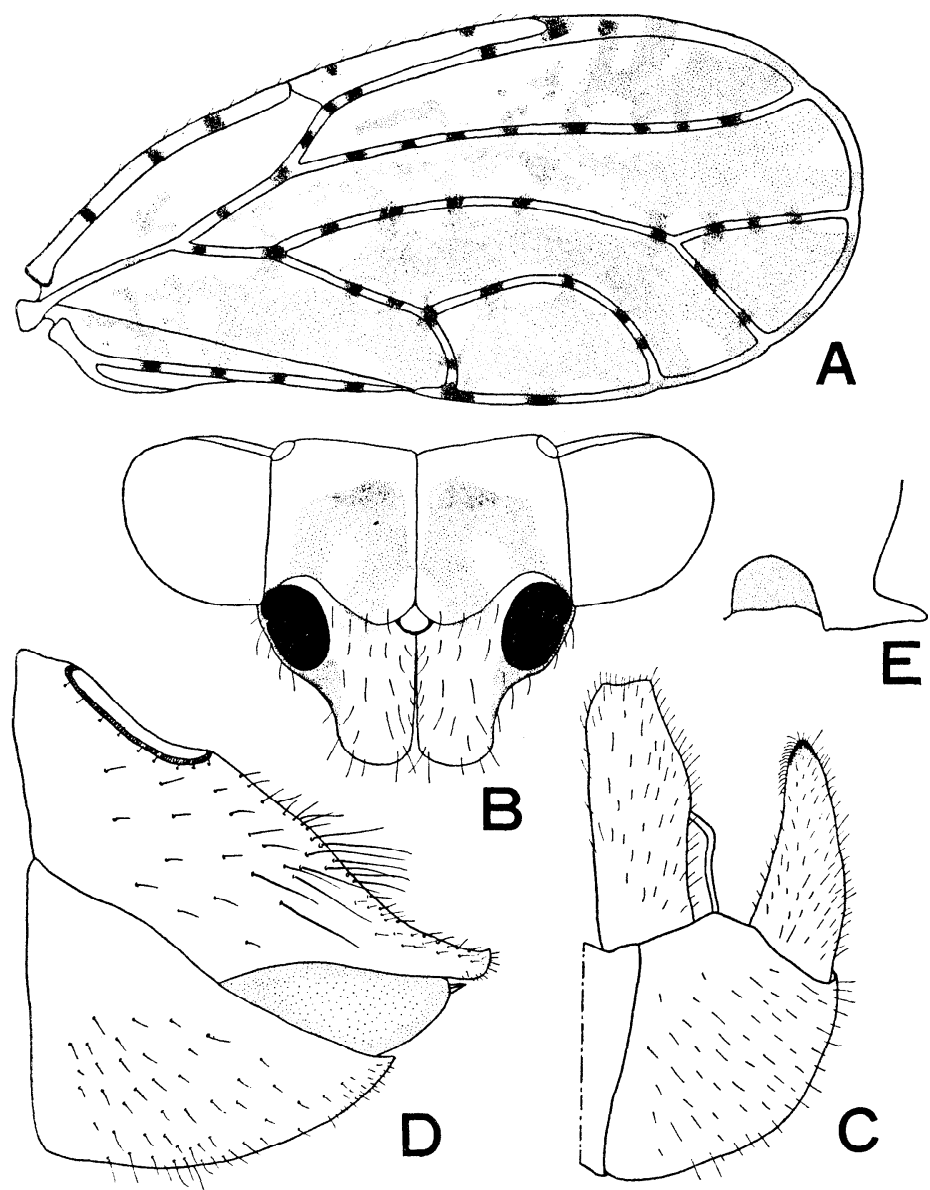

Fig. 8. Psylla multipunctata Y. Miyatake, sp. nov.

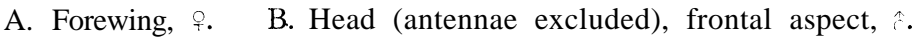

C. Male genitalia, lateral aspect. D. Female genitalia, lateral aspect.

E. Meracanthus, lateral aspect, . 
Para types: $1 \S 2$ ?, the same data as the holotype.

Host plant: unknown.

Differs from any known species of the genus in Japan in having the prominent maculations of forewings and the cubital (first marginal) cell much larger than the medial (second marginal). Differs from the Formosan form of Psyllakuwayamai Crawford (= tripunctata Kuwayama, 1908 nec Fitch, 1851) in being smaller, having in the pterostigma well defined, Rs strongly upturned at apex, $\mathrm{Cu}_{1}$ subparallel with $\mathrm{Cu}_{2}$ so that the cubital cell somewhat parallelogramy, the genal cones not conical but entirely cylindrical, in lacking black spots on praescutum, scutum and metathorax, and in having the proctiger more slender and straight instead of convex posteriorly and distinctly longer than the forceps which are curved cephalad (curved caudad in kuwayamai Crawf.), the female genitalia longer (compared with the type-series of Psyllatripunctata-so, labelled "Arisan, Formosa, 21. iv. 1907, Matsumura," in the Entomological Institute of Hokkaido University).

\section{Psylla hakonensis K uwayama}

Psyllahakonensis Kuwayama, 1908, Trans. Sapporo Nat. Hist. Soc.2: 176.

Distribution: Japan (Honshu, Shikoku, *Kyushu).

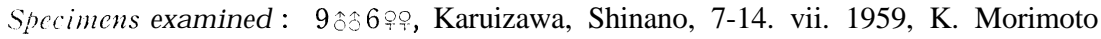
leg. $1: 2 \%$, Mt. Nyuhgasa, Nagano Pref., 29-30. vii. 1962, S. Miyamoto leg. 1 , Komagadake (Isedaki), Nagano Pref., 1. viii. 1962, S. Miyamoto leg. 1, Onnazawa, Ina, Sagan0 Pref., 16. vi. 1962, K. Oshima leg. 16 of 14 , Kitazawa, Yamanashi Pref., 27. vii. 1959, Y. Miyatake leg. $2 \hat{\mathrm{o}}$, Sen jodake-Shirane-Kitadake, Yamanashi Pref., Z-29. vii. 1959, Y. Miyatake leg. 18, Hirayu, Gifu Pref., 28. vii. 1959, M. Miyatake leg. 1우 Mt. Ishizuchi, Iyo, 18. x. 1952, K. Sasaki leg. $38 \hat{\alpha} 8$ 요, Iwaya, nr. Kuma, Iyo, 2. viii. 1955, K. Sasaki leg. $1 \_1 \supsetneq$, Mt. Shibagoya, Zinryo-mura, Awa, 29. ii. 1953, I. Hiura leg. 1乞, Hikosan, Fukuoka Pref., 17. v. 1958, M. Takahashi leg.

Type-specimen examined: 1 from Hakone in the Entomological Institue of Hokkaido University.

Host plants: “Miyama-hannoki "-*Alnus Maximowiczii Call. [Betulaceae]; nymphs \& adults, confirmed at Kitazawa, Yamanashi Pref. in July, 1959 by me. "Dake-kanba "-*Betula Ermani Cham. [Betulaceae] ; nymphs \& adults, confirmed at Kitadake, Yamanashi Pref. in July, 1959 by me.

\section{Psylla ziozankeana K uwayama}

Psyllaziozankeana Kuwayama, 1908, Trans. Sapporo Nat. Hist. Soc. 2: 173.

Distribution : Japan (Hokkaido, *Honshu).

Spccimens examined: 1 ô, Jozankei, Hokkaido, 15. vii. 1953, K. Sasaki leg. 1 , Towada, Tsugaru (alt. 400 m), 7. viii. 1956, K. Baba leg. 1 ? Karuizawa, Shinano, 7-14. vii. 1959, K. Morimoto leg.

Type-specimen examined: 1 from "Ziozankei" in the Entomological Institute of Hokkaido University.

Host plant: unknown. 


\section{Psylla nigriantennata Kuwayama}

Psylla nigriantennata Kuwayama, 1908, Trans. Sapporo Nat. Hist. Soc. 2: 168.

Distribution: Japan (Honshu, Shikoku, *Kyushu).

Specimens examined: 1\%, Karuizawa, Shinano, 7-14. vii. 1959, K. Morimoto leg. 1 , Mt. Zoozu, Sanuki, 1-2. v. 1958, Y. Miyatake leg. 2 우, Mt. Sara, 16. vii. 1954; 1 s. Mt. Ishizuchi, 4. ix. 1953; Ehime Pref., K. Sasaki leg. 1 \& 1 , 29. vi. 1953, Y. Takaishi leg. ; 4 우, 11. v. 1953; 1 6 우, 13. v. 1954; Mt. Tagami, Iyo, K. Sasaki

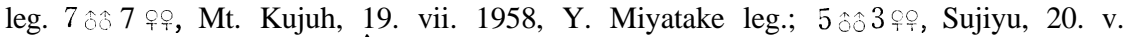
1962, T. Saigusa leg.; Ôita Pref. $1 \hat{\mathrm{C}}$, Hikosan, Fukuoka Pref., 8. vi. 1959, Y. Miyatake leg.

Type-series examined: $1 \lesssim 1 \odot$ from Hakone in the Entomological Institute of Hokkaido University.

Host plant: “ Nejiki "-Lyonia Neziki Nakai et Hara [Ericaceae] ; adults, confirmed at Mt. Tagami, Iyo in May, 1953 by K. Sasaki and Mt. Zoozu, Kagawa Pref. in May, 1958 by me.

\section{Psylla elegantula (Zetterstedt)}

Chermes elegantula Zetterstedt, 1810, Insecta Lapponica : 310

Psylla ornata Meyer-Dür, 1871, Mitth. Schw. Ent. Ges. III : 393, 397.

Distribution : *Japan (Hokkaido), Europe, Russia.

Specimen examined: 1 Hokuchindake, Mts. Daisetsu, Hokkaido, 20. vii. 1962, Y. Miyatake leg.

Host plant: Salix capres L. [Salicaceae ]; Vondráček, 1957: 294 (in Europe !

\section{Psylla matsumurai Y. Miyatake, sp. nov.}

(Fig. 9, A-F)

: General colour shiny black with orange stripes or irregular maculation or spots as follows: vertex along median line and posterior margin and between antennal socket and lateral ocelli, posterior edge of eyes, a few spots on pronoturn, T-shaped maculation and anterior angles of praescutum, a few pairs of longitudinal stripes on scutum, anterior angles of scutellum, apical half or tips of anterior and middle femora, all tibiae and intersegmental membrane of abdomen orange. Genal cones black but slightly orange or reddish brown on central portion. Forewings semitransparent, somewhat white, with veins black.

Head (Fig. 9, B) slightly wider than thorax, somewhat deflexed; vertex shorter than half as long as wide, slightly below plane of pronotum, with posterior margin scarcely incised, rugose, with discal depressions rather deep and sunken widely, raised anteriorly and along posterior margin; frons and occiput not visible; genal cones long, slender, fully as long as vertex, subacute at apex, distinctly divergent, with long pubescence throughout; eyes hemispherical; antennae short and stout, 1.4 times as long as width of head, with two apical setae of the same length, relative lengths of the antennal segments as $3: 3: 8: 5: 5: 5$ : $5: 4: 2: 3$

Thorax broad, arched, not pubescent, less rugose than vertex ; pronotum 
somewhat deflexed, convex above plane of vertex, half as long as vertex, nearly as wide as head; praescutum shorter than wide, about $10 \times 17$, with posterior margin straight. Legs stout, hairy; posterior tibia with a minute projection but without any prominent basal spur, with 2 outer and 3 inner apical spines; proximal segment of posterior tarsus with a pair of apical spines; meracanthus short, acute, pro jected ventro-caudad. Forewings (Fig. 9, A) elongate, 2.4 times as long as wide, narrowly rounded at apex, with anterior margin pubescent to
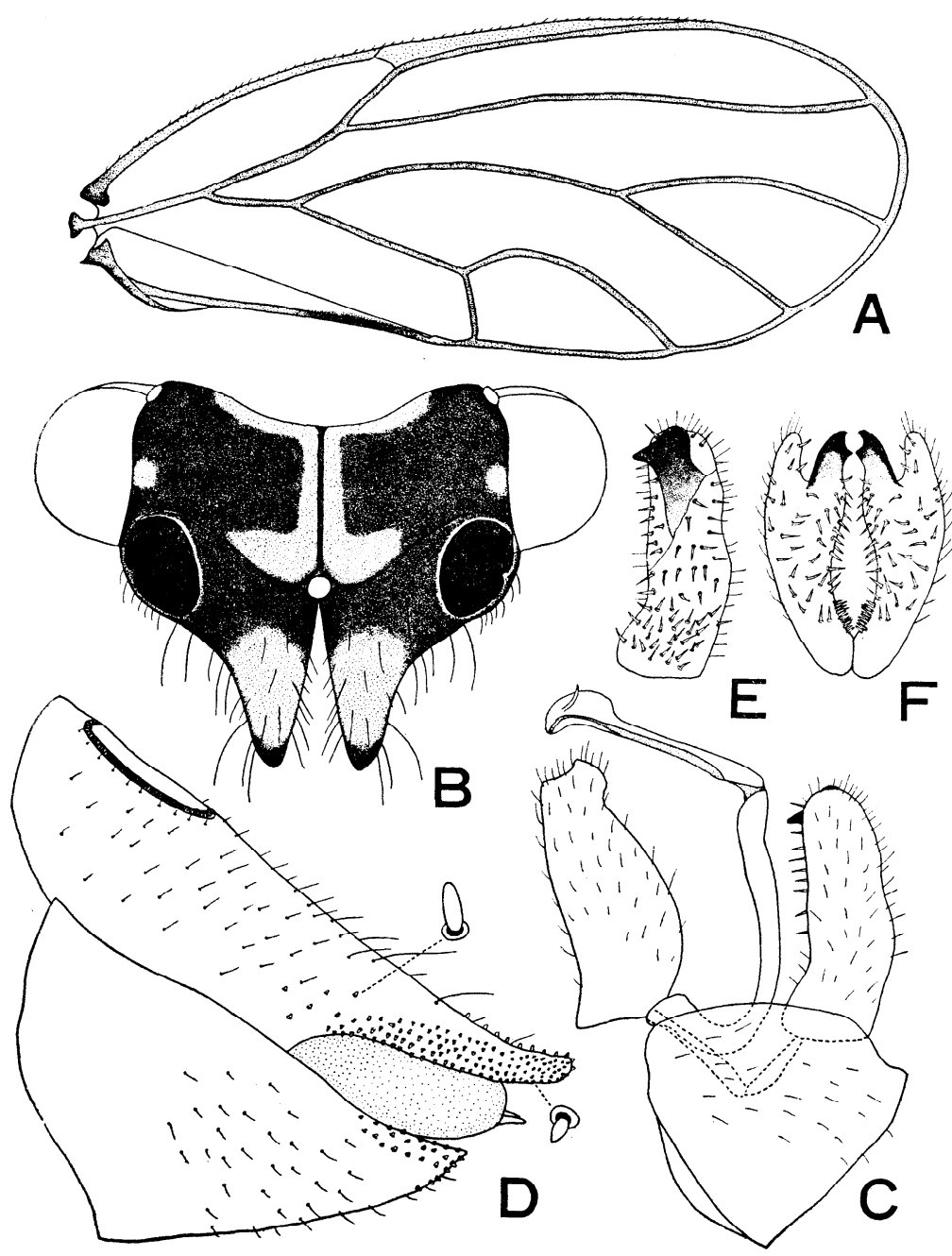

Fig. 9. Psylla matsumurai Y. Miyatake, sp. nov.
A. Forewing, $\hat{\imath}$.
B. Head (antennae excluded), frontal aspect, ?.
C. Male genitalia, lateral aspect.
D. Female genitalia, lateral aspect.
E. Male forceps, inner face.
F. Male forceps, caudal aspect. 
tip of pterostigma; pterostigma long and broad, 0.75 times as long as Rs, basally closed; Rs very slightly sinuate, reaching almost apex of wing, more or less upturned at tip; M-stem weakly arched; $\mathrm{Cu}_{2}$ short, almost perpendicular; medial (second marginal) cell larger than cubital; cubital (first marginal) cell small, lower than wide, half as high as wide; relative lengths of the veins $\mathrm{M}+\mathrm{Cu}, \mathrm{Cu}, \mathrm{Cu}_{2}$, $\mathrm{M}_{1+2}$ and $\mathrm{M}_{3+4}$ as $1: 2.2: 7: 2.9: 2.1$. Abdomen (excl. genital segments) long, almost as long as thorax, sparsely pubescent ventrally.

Male genital segments (Fig. 9, C) small, short, 0.3 times as long as the rest of abdomen, with dense, white hairs throughout; proctiger in lateral aspect short but distinctly longer than forceps, straight, with anterior margin produced cephalad and posterior margin almost straight, narrow apically, truncate horizontally at apex; forceps in lateral aspect slender, constricted near base, slightly curved cephalad and bluntly rounded apically, with inner face bearing a large, sclerotized tooth mesad on apical third as figured (Fig. 9, E), reaching apex of forceps, in caudal view (Fig. 9, F) heavy at base, strongly arched, bifid apically, with inner tooth acute and innerly curved apically, with inner face bearing short, strong setae on basal portion, in dorsal view inner tooth notched near midpoint, produced mesad anteriorly and posteriorly ; aedeagus short, thickened at base and transformed as beak-like, with first segment 1.4 times as long as second; subgenital plate nearly as high as proctiger, heavily sclerotized, somewhat quadrilateral, with dorsal margin almost straight in the basal two-thirds and descending (downcurved) in the apical third, with apical portion separated with broad suture making narrow sclerite cephalad, in caudal view with dorsal margin strongly incised. Female genital segments (Fig. 9, D) shorter than the rest of abdomen, shortly pubescent; dorsal valve very slender, distinctly longer than ventral, rather wide basally and attenuate in apical half, blunt and spinose apically, with dorsal margin slightly sinuate and not upturned apically ; inner valve shorter than dorsal and longer than ventral; ventral valve broad in lateral aspect, somewhat right-angled-triangular, sharp and not upturned at tip.

Length of body $1.4-1.7 \mathrm{~mm}, 2.1-2.3 \mathrm{~mm}$ (to tip of folded wings $2.8-3.0$ $\mathrm{mm}, 53.0-3.2 \mathrm{~mm}$ ); length of forewing $2.2-2.5 \mathrm{~mm}, 92.6-2.7 \mathrm{~mm}$; length of

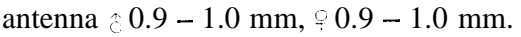

Distribution: Japan (Hokkaido).

Holo type ( $)$ : Utsukushiga-hara $(1850 \mathrm{~m})$, Mts. Daisetsu, Kamikawa-gun, Hokkaido, 22. vii. 1962, Y. Miyatake leg. (on Salix Reinii Franch. et Sav.).

Puratypes: 454499 ( $352 \%$ on slides), the same data as the holotype on the same host.

Named in honor of the late Dr. Shônen Matsumura.

Host plant: "Miyama-yanagi " or "Mine-yanagi "-Salix Reinii Franch. et Sav. [Salicaceae]; adults, nymphs and eggs, confirmed at Utsukushiga-hara, Mts. Daisetsu in July, 1962 by me.

Differs from the known species of the genus in having the prominent forceps with a large, black tooth on inner surface as figured, apex of tooth produced both cephalad and caudad, anterier portion acute and posterior portion bluntly rounded.

\section{Psylla horii K uwayama, J r.}

Psylla liorii Kuwayama, Jr., 1913, Trans. Nat. Mist. Soc. Taiwan 33: E07, fig. 2. 
Distribution: Japan (Yakushima, *Tsushima).

Specimen examined: $1 \hat{\delta}$, Mt. Tatera, Azamo, Tsushima, 13. vii. 1960, H. Kamiya leg.

Type-series examined : holotype ( $\hat{)}$ ) and allotype (?) from Anbo, Yakushima, in the collection of Kyushu University.

Host plant: unknown.

\section{Psylla pyrisuga Förster}

Psylla pyrisuga Fdrster, 1818, Verh. naturw. Ver preuss. Rhein. 3: 78.

Chermes pyri Schmidberger, 1827, Beitr. z. Nat. Schadl. Ins. 1: 179-195.

Psylla austraca Flor, 1861, Kat. d. Rhynch. : 372.

Psylla aurantiaca Goureau, 1862, Ins. nuisibles : 34 .

Psylla rutila Meyer-Diir, 1871, Mitth. Schw. Ent. Ges. 3 :394, 397, 871.

Psyllarufitarsis Meyer-Diir, 1871, ibid. : 394, 398.

Distribution: Japan (Hokkaido, Honshu, Shikoku, Kyushu), Europe, Russia, Korea.

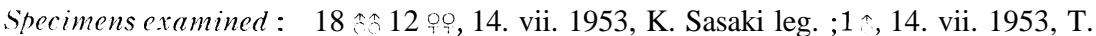
Ishihara leg. ; Sapporo, Hokkaido. $3 \%$, Aizankei, Kamikawa-gun, 18. vii. 1962, Y. Miyatake leg. 5 so 3 , Kotoni, Sapporo, 16. v. 1957, S. Iwabayashi leg. 6 , 4 13. vii. 1962, T. Saigusa leg.; $1 \hat{1}$ ㅇ, 14. vii. 1962, Y. Miyatake leg. ; Takada-

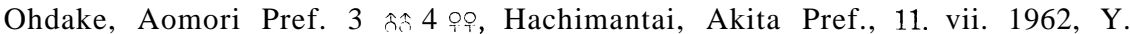
Miyatake leg. 1ㅇ, Mt. Tokura, Ina, Nagano Pref., 6. vi. 1962, K. Hara leg. 2 ^^ 1․, Tarumi, Matsuyama, 11. v. 1953; 1^2 2 ơ, Mt. Tagami, 13. v. 1954 ; Ehime Pref., K. Sasaki leg. $1 \uparrow 1 \%$, 15. iii. 1953, T. Edashige leg. ;1ๆ, 1. v. 1952, T. Ishihara leg. ; Higashino, Matsuyama. 5 个 6 , 5. ix. 1953, K. Sasaki leg. ; 1 , 30. vii. 1918, A. Tashima leg.; Mt. Ishizuchi, Ehime Pref. (The Japanese examples were compared with the European ones with Dr. Eastop's favour of the British Museum.)

Host plants: "Nashi"-Pyrus serotina Rehder [Rosaceae]; adults, confirmed in Matsuyama in May, 1953 by K. Sasaki. “ Ringo "-Maluspumila Mill. var. dulcissima, Koidz. [Rosaceae]; Matsumura, $1917: 371$.

\section{Psylla vaccinii Y. Miyatake, sp. nov.}

(Fig. 10, A-E)

fo: General colour testaceous or reddish brown, but greenish brown in the newly-emerged form; occiput, two apical segments and tips of antennae, anterior margin of pronotum and praescutum, broad band on mesopleurite, sternites of abdomen, tips of male forceps and apical spines of posterior tibia and tarsus black or dark brown; genal cones green or greenish white ; eyes reddish brown ; ocelli dull yellow. Forewings transparent, not coloured at tip of clavus, with veins brown. Female genitalia more or less brownish, darker at base and apex.

Head (Fig. 10, B) definitely wider than thorax, vertical ; vertex slightly shorter than half as long as wide, almost on same plane of pronotum, with posterior margin incised, with discal depressions weak; frons well covered with vertex; occiput visible only laterally in caudal view; antennal socket pubescent innerly ; genal cones slightly shorter than vertex on median line, slender, blunt but 
somewhat truncate obliquely at apex, rather parallel to each other but weakly divergent apically, sparsely pubescent throughout ; antennae short, rather stout, hairy, 1.4 times as long as width of head, with two apical setae of the same length, relative lengths of the antennal segments as $2: 3: 8: 5: 5: 5: 5: 5: 3: 3$.

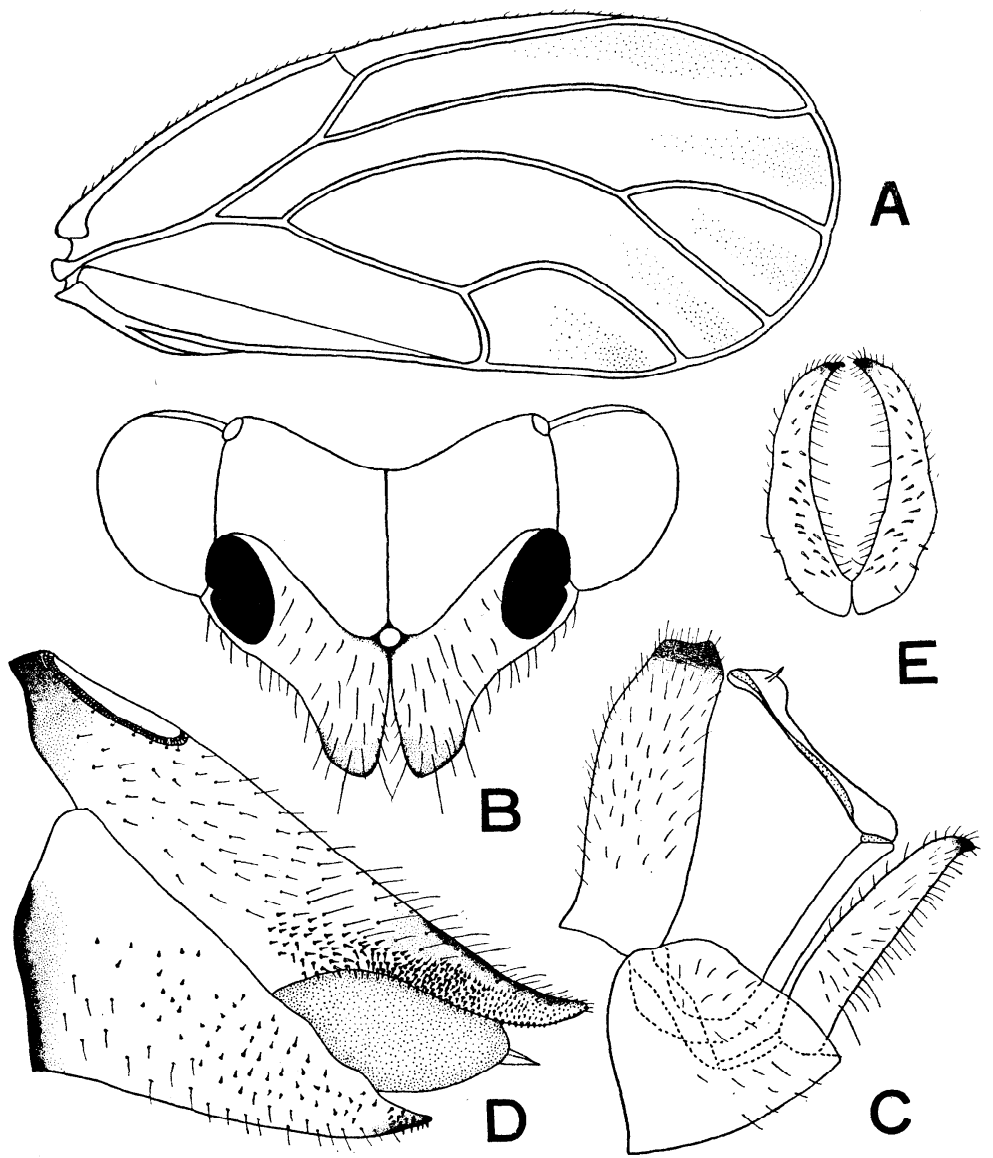

Fig. 10. Psylla vaccinii Y. Miyatake, sp. nov.
A. Forewing, $\hat{0}$.
B. Head (antennae excluded), frontal aspect,
C. Male genitalia, lateral aspect.
D. Female genitalia, lateral aspect.
E. Male forceps, caudal aspect.

Thorax typically robust, arched, not pubescent; pronotum subvertical, produced cephalad and laterad, very short, half as long as vertex in frontal view, with posterior margin incised; praescutum shorter than wide, about $11 \mathrm{x} 17$; scutum half as long as wide, continuous to' subtrapezoidal scutellum, slightly depressed centrally. Legs short, stout; posterior tibia with a basal spur minute and not prominent, with 1 outer and 4 inner apical spines; proximal segment of posterior 
tarsus with a pair of apical spines; meracanthus short, as long as apical segment of antennae, projected ventro-caudad in lateral aspect, acute at apex. Forewings (Fig. 10, A) elongate, 2.3 times as long as wide, narrow basally and broad apically, broadly rounded at apex, with anterior margin hairy almost to tip of Rs; pterostigma broad but short, about half as long as Rs, basally closed; Rs bisinuate, not upcurved at apex ; $\mathrm{M}$ strongly arched; $\mathrm{Cu}_{1}$ long, strongly arched, subparallel with $\mathrm{M}_{3+4}$, relative lengths of the veins $\mathrm{Cu}+\mathrm{M}, \mathrm{Cu}, \mathrm{Cu}_{2}, \mathrm{M}_{1+2}$ and $\mathrm{M}_{3+4}$ as $1: 2.3: 1.1: 2.7: 2.5$; cubital (first marginal) cell quadrate, lower than wide, about $15 \times 23 ; \mathbf{C}+\mathbf{S c}$ thickened regularly. Abdomen (excl. genital segments) short, half as long as width of forewings, constricted at base, broadened on basal third then narrowed to genital segments, pubescent ventrally.

Male genital segments (Fig. 10, C) small, about half as long as the rest of abdomen, the pubescent; proctiger in lateral view nearly straight, as long as forceps, broad mostly but narrowed apically, truncate horizontally at apex, slightly curved caudad apically ; forceps in lateral view long, slender, somewhat sickle-shaped, tapering to subacute apex, in caudal view (Fig. 10, E) strongly arched, broad at base, tapering to acute and touched apices, with inner face bearing long, retrorse setae; aedeagus short, with first segment hook-shaped and 1.3 times as long as second segment, with second segment transformed as somewhat hemispherical as figured (Fig. 10, C); subgenital plate as high as proctiger, in caudal view (Fig. 10, E) with dorsal margin strongly incised. Female genital segments (Fig. 10, D) very long comparing with small body, conspicuously longer than the rest of abdomen, sharp and slender; dorsal valve slender, longer than ventral, distinctly characterized as figured, with dorsal margin almost straightly descending and upturned apically, with apical half narrowed and acute at apex; anus small, in larger diameter half as long as the rest of dorsal valve; inner valve slightly shorter than dorsal and distinctly longer than ventral ; ventral valve acute and upturned apically, with dorsal margin sinuate.

Length of body $1.4-1.6 \mathrm{~mm}$, $\quad 1.8-2.1 \mathrm{~mm}$ (to tip of folded wings $2.5-2.8$ $\mathrm{mm}$, $2.7-3.0 \mathrm{~mm}$ ); length of forewing $\$ 2.1-2.4 \mathrm{~mm}$, $2.3-2.5 \mathrm{~mm}$; length of antenna $\hat{c}$ 0.9-1.0 mm, 우 0.9-1.0 mm.

Distribution : Japan (Kyushu, Shikoku).

Holotype (s): Mt. Zoozu, Sanuki (Kagawa Pref.), Shikoku, 1-2. v. 1958, Y. Miyatake leg. (on Vacciniumbracteatum Thunb.).

Paratypes: 6 송 5 우, the same data as the holotype on the same host. 4 르, Nakadote, Matsuyama City, Shikoku, 10. vi. 1953, K. Sasaki leg. 3 sô 2 우, 11. v. 1953; 7 â 1 a, 13. v. 1954; 5 ố 3o, 23. vi. 1954 ; Mt. Tagami, Ehime Pref., Shikoku, K. Sasaki leg. 1 으, Mt. Takanawa, Iyo (Ehime Pref.), Shikoku, T. Mohri leg. 10 5 - , Harumachi, nr. Fukuoka City, Kyushu, 10. vi. 1958, Y. Miyatake leg. 1 c, Hirao, Fukuoka City, Kyushu, 24. ii. 1959, Y. Miyatake leg. 1 $\hat{\circ}$, Tajima, Fukuoka City, Kyushu, 28. v. 1958, Y. Miyatake leg. 1 , 30. iii. $1958 ; 3$ \& 2 (on slides), 6. v. 1959; Mt. Tachibana, Fukuoka City, Kyushu, Y. Miyatake leg.

Host plant: "Shashanbo "-Vacciniumbracteatum Thumb. [Ericaceae] ; adults, confirmed at Mt. Tagami, nr. Matsuyama City in May, 1953 by K. Sasaki and Mt. Zoozu, Kagawa Pref. in May, 1958 by me; adults \& nymphs, confirmed at Harumachi, nr. Fukuoka City in June, 1958 by me.

Differs from nigriantennata Kuwayama in being much smaller, in having the antennae shorter than 1.5 times as long as width of head and not wholly black, the genal cones much shorter than the vertex and obliquely truncate at apex 
(longer than the vertex and more or less cylindrical and truncate horizontally in nigriantennata Kuw.). Differs from ledi Flor in having the forceps more slender and longer, the dorsal valve of the female genitalia more stout and acute at apex.

\section{Key to the species of Psylla from Japan proper}

1 (2). Frons visible as a small sclerite, bearing front ocellus; genae swollen beneath into two more or less conical processes, these usually quite separated at base and not separable from vertex

1. sasakii Y. Miyatake

2(1). Frons not visible, covered by genae, except a very narrow border around front ocellus; genae produced as distinct genal cones, touched at base, separated from vertex with suture distinctly

3 (22). Antennae fully twice as long as width of head or longer ...................4

4 ( 7 ). Antennae longer than 3 times as long as width of head .................. 5

5 (6). Female genital segments shorter than the rest of abdornen; body light brown with brown stripes on thorax; forewings 2.5 times as long as wide; length of body: $\$ 3.8 \mathrm{~mm}$, $5 \mathrm{~mm}$ 2. magnifera Kuwayama

6 (3). Female genital segments longer than the rest of abdomen ; body yellowish or green ; forewings 2.3 times as long as wide ; length of body: $\uparrow 3.0-$ $3.2 \mathrm{~mm}$, o $4.0-4.4 \mathrm{~mm}$

3. alni (Linné)

7 (4). Antennae less than 2.5 times as long as width of head 8

8 (9). Forewings with pterostigma obsolete, I/ S as long as R

4. omogoensis $\mathrm{Y}$. Miyatake

9 ( 8 ). Forewings with pterostigma well defined, more than half as long as Rs

10 (11). Antennae 2.4 times as long as width of head or longer

5. morimotoi $Y$. Miyatake

11 (10). Antennae less than 2.3 times as long as width of head .................... 12

12 (13). Male forceps narrow basally and strongly enlarged apically ................ 13

13(14). Forewings transparent, with 3 distinct black spots on posterior margin, in cubital cell, between $\mathrm{M}_{3+4}$ and $\mathrm{Cu}_{1}$, and in medial cell; female genital segments as long as the rest of abdomen or slightly longer, inner valve shorter than dorsal; Rs strongly bisinuate ........ 6. hexastigma Horváth

14 (13). Forewings more or less flavous, without 3 black spots on posterior margin ; female genital segments distinctly longer than the rest of abdomen (almost 1.5 times) ; inner valve much longer than dorsal ; Rs slightly arched

7. betulae (Linne)

15 (12). Male forceps simply straight-margined or tapering towards apex $\ldots . . .16$

16(17). Male proctiger as long as forceps or shorter, strongly produced caudad basally as a posterior lobe; vertex distinctly longer than half as long as wide; body red ............................................ 8. midoriae Y. Miyatake

17 (16). Male proctiger distinctly longer than forceps, not produced caudad, with posterior margin more or less straight; vertex half as long as wide or shorter; body not red ............................................................... 18

18 (21). Female genital segments shorter than the rest of abdomen, dorsal valve in lateral aspect blunt apically, not strongly upturned 
19 (20). Forewings with cubital cell elongate, almost as wide as high, with $\mathrm{Cu}_{1}$ and $\mathrm{Cu}_{2}$ subparallel to each other; dorsal valve of female genitalia rather broad and truncate apically ; genal cones broad, distinctly shorter than vertex, contiguous, obliquely truncate apically

9. amakusensis Kuwayama, Jr.

20 (19). Forewings with cubital cell broad, nearly twice as wide as high, with Cur and $\mathrm{Cu}_{2}$ not subparallel; dorsal valve of female genitalia strongly attenuate and subacute apically; genal cones almost as long as vertex, slender, moderately divergent, subacute at apex ........ 10. viburnii Löw

21 (18). Female genital segments longer than the rest of abdomen, dorsal valve in lateral aspect sharply acute apically and strongly upturned (Fig. 3, C); forewings dark brown with a transparent area near $\mathrm{Cu}_{2}$, with a large black spot at tip of clavus 11. fulguralis Kuwayama

22 (3). Antennae distinctly less than twice as long as width of head . . . . . . . 23

23 (42). Antennae distinctly shorter than 1.3 times as long as width of head

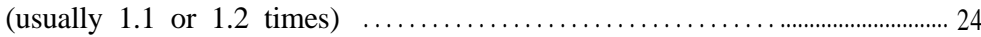

24 (25). Forewings with a distinct broad band of brownish colour along posterior margin and $\mathrm{Cu}$ from tip of $\mathrm{Rs}$ to base of $\mathrm{M}+\mathrm{Cu}$; body large, more than $4.0 \mathrm{~mm}$............................................12. yasumatsui $\mathrm{Y}$. Miyatake

25 (24). Forewings without a distinct broad band along posterior margin; body small, less than $2.5 \mathrm{~mm} \ldots \ldots \ldots \ldots \ldots \ldots \ldots \ldots \ldots \ldots \ldots \ldots \ldots \ldots \ldots \ldots \ldots \ldots . . .26$

26 (29). Male forceps strongly enlarged, with a secondary lobe, inner face with prominent, tubercular setae ................................................. 27

27 (28). Male forceps shorter than half as long proctiger, apex notched near midpoint, apically with an acute, sclerotized projection cephalad ..........

13. malivorella [Sasaki]

$28(27)$. Male forceps longer than half as long as proctiger, apex nearly truncate horizontally, apically with an acute, sclerotized projection caudad

14. sorbicola Y. Miyatake

$29(20)$. Male forceps more or less slender, without a secondary lobe, inner face without strong setae ............................................................ 30

30 (31). Male proctiger short, as long as forceps or shorter .........................

............................................................. 15. jetoensis Y. Miyatake

31 (30). Male proctiger more or less longer than forceps (usually distinctly longer) ............................................................................ 32

32 (33). Male proctiger strongly produced caudad as a distinct lobe in the basal half, very narrow in the apical half; marginal cells of forewings markedly long and narrow ..................16. jamatonica Kuwayama (autumn form)

33 (32). Male proctiger not produced caudad, with posterior margin more or less straight; marginal cells of forewings moderately long ...................34

32 (39). Forewings more or less transparent or whitish-smoky $\ldots \ldots \ldots \ldots \ldots \ldots \ldots .35$

35 (35). Dorsal valve of female genitalia acutely pointed and strongly upturned apically (Fig. 3, B); male forceps curved caudad

17. elaeagnicola $Y$. Miyatake

36 (35). Dorsal valve of female genitalia not acutely pointed nor upturned apically; male forceps more or less curved cephalad

37 (38). Male forceps in lateral aspect broad basally, strongly narrowed towards apex which is acute and strongly curved cephalad ; dorsal valve of female genitalia rounded at apex............................ 18. tenuata Jensen 
38 (37). Male forceps in lateral aspect slender throughout; dorsal valve of female genitalia obliquely truncate at apex ..............19. melanoneura Förster

39 (34). Forewings not transparent, distinctly brownish or flavous . . . . . . . . 30

40 (41). Genal cones broad, obliquely truncate apically, contiguous ; forewings dark brown, with cubital (first marginal) cell elongate, 0.7 times as wide as high ............................................20. satsumensis Kuwayama

41 (40). Genal cones very slender, tapering, subacute apically, more or less divergent; forewings flavous, with cubital (first marginal) cell wide, almost twice as wide as high .................................. 21. aisanensis Y. Miyatake

42 (23). Antennae longer than 1.3 times as long as width of head . . . . . . . . . . 43

43 (84). Antennae distinctly longer than 1.5 times as long as width of head (usually more than 1.6 times), slender ...............................4.4

44 (45). Male proctiger strongly produced caudad basally as a posterior lobe, nearly as long as forceps; forewings with black spots on veins irregularly; genal cones slightly shorter than vertex, broad, rounded apically, rather contiguous ..................................22. kuwayamai Crawford

45 (44). Male proctiger not produced caudad, with posterior margin more or less straight; forewings without black spots on veins .................... 46

46 (49). Marginal vein of forewing black at tip of $\mathrm{Cu}_{2}$; genal cones broad, contiguous, more or less truncate apically ................................... 47

47 Forewings somewhat rhomboidal, twice as long as wide, distinctly opaque along marginal vein throughout, with veins brown, with Rs not upturned, with cubital (first marginal) cell smaller than medial, 1.3 times as long as high; male forceps slender, straight, narrowed to apex

24. japonica Kuwayama, Jr.

48 (47). Forewings elongate, 2.2 times as long as wide, opaque entirely, with veins white, with Rs strongly upturned towards anterior margin, with cubital (first marginal) cell wide, 2.2 times as long as high; male forceps sinuate, parallel-margined to apex which is curved caudad

25. albovenosa Kuwayama

49 (46). Marginal vein of forewing not black at tip of $\mathrm{Cu}_{2} \ldots \ldots \ldots \ldots \ldots \ldots \ldots . .50$

50 (53). Forewings with veins light brown or brown in the basal third or half, dark brown or black in the apical two-thirds or half; antennae 1.6 times as long as width of head ; genal cones as long as vertex or longer . . 51

51 (52). Female genital segments long, slender, almost twice as long as the rest of abdomen ; male forceps stout? produced cephalad as an acute, hook-shaped projection and strongly sclerotized apically ; genal cones slender, rather contiguous ...................................23. haimatsucola $\mathbf{Y}$. Miyatake

52 (51). Female genital segments short, broad, nearly as long as the rest of abdomen ; male forceps slender, rather straight, blunt apicalfy ; genal cones broad, more or less divergent ........................ 26. tobirae Y. Miyatake

53 (50). Forewings with veins unicoloured ..................................... 54

54 (55). Male forceps enlarged throughout, almost as broad as apical half of proctiger, curved caudad and strongly sclerotized apically, rather acute at apex, with both anterior and posterior margins bisinuate; host plants: Salix spp. 27. pulchra (Zetterstedt)

$5 \overline{5}$ (54). Male forceps more or less slender, tapering or narrowed towards apex 
56 (67). Forewings with a prominent, black spot or marking at apex of clavus . .

57 (60). Dorsal valve of female genitalia acutely pointed as thorn-like and strongly upturned apically

js (59). Forewings with 4 additional, black or brown markings or maculae besides one at apex of clavus along posterior margin, in cubital cell, in medial cell, between $\mathrm{M}_{3+4}$ and $\mathrm{Cu}_{1}$, and between $\mathrm{Rs}$ and $\mathrm{M}_{1+2}$; hindwings rather conspicuously brown along posterior margin; genal cones distinctly shorter than vertex, rather broad; antennae 1.6-1.7 times as long as width of head ...................................... 28. clacagni Kuwayama

59 (58). Forewings without any markings except for one at apex of clavus; hindwings not brown along posterior margin; genal cones almost as long as vertex, slender, divergent; antennae more than 1.8 times as long as width of head

29. kiushucnsis Kuwa ya ma

60 (57). Dorsal valve of female genitalia not pointed nor strongly upturned, but

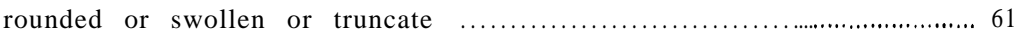

61 (62). Forewings fumate or opaque; genal cones stout, nearly as long as wide at base, contiguous, obliquely truncate apically ..... 30. abicti Kuwayama

62 (61). Forewings more or less transparent; genal cones rather slender and conical, more or less longer than wide at base ......................... 63

63 (66). Genal cones fully as long as vertex or longer; antennae long, more than 1.7 times as long as width of head; dorsal valve of female genitalia

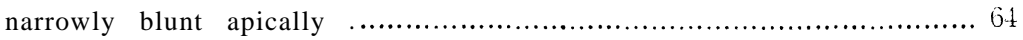

$64(65)$. Genal cones wholly white, broad, slightly divergent; body red with white markings ........................................... 31. albigena Y. Miyatake

65 (64). Genal cones not white but yellowish brown, slender, strongly divergent (Fig. $\overline{5}, \mathrm{~B})$; body brown with distinct black stripes on thorax . . . . . . . . . . 32. fatsiac Jensen

66 (63). Genal cones distinctly shorter than vertex ; antennae comparatively short, less than 1.6 times as long as width of head; dorsal valve of female genitalia rather broad, truncate apically

33. torocnensis Kuwayama

$67(53)$. Forewings without a prominent, black spot or marking at apex of clavus 68

68 (71). Female genital segments distinctly longer than the rest of abdomen, usually more than 1.5 times; forewings more or less fumate .......... 69

$69(70)$. Genal cones broad, almost as long as broad at base, rounded apically, slightly divergent; apex of dorsal valve conspicuously upcurved and subacute; pterostigma of forewing narrow and short, half as long as Rs

34. carpinicola Crawford

70 (69). Genal cones conical, slender, subacute and granulated at apex, prominently divergent; apex, of dorsal valve of female genitalia curved ventrad and rounded; pterostigma of forewing broad and long, 0.7 times as long as Rs

35. hartigii Flor

$71(68)$. Female genital segments distinctly shorter than the rest of abdomen . . . 72

72 (77). Genal cones distinctly shorter than vertex, rather broad, contiguous . . . 73

73 (74). Body entirely red or scarlet in colour; vertex half as long as wide ...... 
74 (73). Body not red but brown or greenish yellow; vertex longer than half as long as wide ........................................................................ 75

75 (76). Genal cones stout, broadly rounded apically ; dorsal valve of female genitalia rather broad at apex, with dorsal margin upcurved apically ; thorax without distinct black stripes on scutum

37. hederae Y. Miyatake

76 (75). Genal cones rather conical, subacute or obliquely truncate apically ; dorsal valve of female genitalia narrowly attenuate apically, with dorsal margin not upcurved apically; thorax with distinct black stripes on scutum 38. moiwasana Kuwayama

77 (72). Genal cones nearly as long as vertex or slightly shorter, slender, conical,

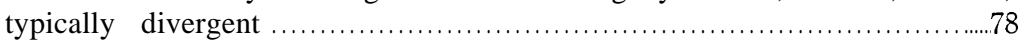

78 (79). Male proctiger straight, not curved caudad apically

39. ambigua Förster

79 (78). Male proctiger strongly curved caudad apically .......................... 80

80 (81). Antennae shorter than 1.7 times as long as width of head; cubital (first marginal) cell of forewing less than 1.4 times as wide as high (Fig. 7, A);

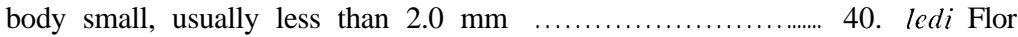

81 (80). Antennae longer than 1.8 times as long as width of head; cubital (first marginal) cell of forewing more than 1.7 times as wide as high; body usually more than $2.0 \mathrm{~mm}$

82 (83). Discal depressions of vertex quite deep and located near posterior margin ; cubital cell of forewing 1.8 times as wide as high; genal cones rather broad 41. mali (Schmidberger)

83 (82). Discal depressions of vertex indistinct; cubital (first marginal) cell of forewing rather wide, fully 2 times as wide as high; genal cones conspicuously slender

42. peregrina Förster

84 (43). Antennae shorter than 1.5 times as long as width of head or scarcely 1.5 times as long as (usually less than 1.4 times), often stout ................ 85

85 (86). Forewings with veins alternately black (or dark brown) and white with irregular intervals, with brown maculae on membrane; cubital (first marginal) cell somewhat rectangular, much larger than medial; genal cones cylindrical, broadly rounded or truncate horizontally

43. multipunctata Y. Miyatake

86 (85). Forewings with veins without black or dark spots on them but unicoloured .......................................................................... 87

87 (88). Genal cones quite short, half as long as vertex, distinctly shorter than wide at base, shortly pubescent, each cone with a single, long (longer than genal cone) seta laterally near apex; male proctiger strongly produced caudad as a posterior lobe basally

16. jamatonica Kuwayama (summer form)

88 (87). Genal cones nearly as long as vertex, more or less longer than wide at base, usually densely pubescent, each cone without a single, long seta near apex; male proctiger not produced caudad, with posterior margin

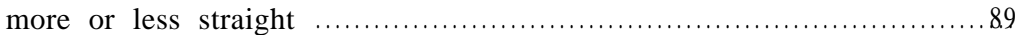

89 (90). Forewings dark brown or with numerous dark brown spots or maculae in the apical half ...............................41. hakonensis Kuwayama

90 (89). Forewings transparent or flavous, without dark spots …..............91 
91 (96). Female genital segments distinctly longer than the rest of abdomen, (usually more than 1.5 times) ........................................................ 92

92 (93). Apex of dorsal valve of female genitalia acutely pointed and strongly upturned apically; vertex distinctly shorter than half as long as wide ; genal cones broad, nearly as long as broad

45. ziozankeana Kuwayama

93 (92). Apex of dorsal valve of female genitalia rounded and not upturned apically; vertex half as long as wide or longer ; genal cones slender, more or less conical .......................................................... 94

94 (95). Dorsal valve of female genitalia rather broad and obliquely truncate apically, with dorsal margin bisinuate; genal cones as long as vertex or longer, slender, contiguous, obliquely truncate apically

46. nigriantennata Kuwayama

95 (94). Dorsal valve strongly attenuate and narrowly rounded apically, with dorsal margin straight throughout; genal cones shorter than vertex, conical, divergent, subacute apically

47. clegantula Zetterstedt

96 (91). Female genital segments as long as the rest of abdomen or distinctly shorter

97 (98). Male forceps with a large, prominent, black tooth on inner surface ...... .48 matsumurai $Y$. Miyatake

98 (97). Male forceps without a tooth on inner surface 99

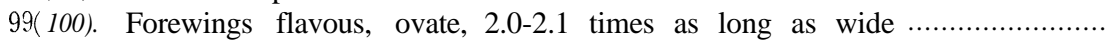
49. horii Kuwayama, Jr.

100 (99). Forewings transparent, rather elongate, more than 2.2 times as long as wide 101

101(102). Genal cones broad, rounded apically; dorsal valve of female genitalia short, half as long as the rest of abdomen, rounded apically; male forceps broad, nearly parallel margined ; body $2.4--2.7 \mathrm{~mm}$

50. pyrisuga Förster

102(101). Genal cones rather slender, obliquely truncate apically; dorsal valve of female genitalia long, as long as the rest of abdomen, acute apically; male forceps slender, tapering towards acute apex; body $1.4-2.1 \mathrm{~mm} \ldots$

51. uaccinii $Y$. Miyatake

\section{REFERENCES}

Aulmann, G. (1913) : Psyllidarum Catalogus. W. Junk, Berlin W. 15.

Boselli, F. B. (1930) : Studii sugli Psyllidi VI, Psyllidi di Formosa racolti del Dr. R. Takahashi. Boll. Lab. Zool., R. Inst. sup. agr., Portici 24: 175-210.

Brittain, W. H. (1923): The morphology and synonymy of PsylliamaliSchmidberger. Proc. Acad. Ent. Soc. 8: 23-42.

Crawford, D. L. (1911): American Psyllidae III (Triozinae). Pomona Coll. J. Ent. 3: 422-453, figs. $152-155$.

Crawford, D. L. (1911): American Psyllidae IV (A partial revision of Subfamilies). Pomona Coll. J. Ent. 3: 480-503, figs. 157-160.

Crawford, D. L. (1914): A monograph of the jumping plant-lice or Psyllidae of the New World. U. S. Nat. Mus. Bull. 85. 186 pp, 30 pls. 
Crawford, D. L. (1919): The jumping plant-lice of the Palaeotropics and the South Pacific Islands, family Psyllidae, or Chermidae, Homoptera. Phil. J. Sci. 15 (2):139-207, pls. I-III.

Ferris, G. F. \& Klyver, F. D. (1932) : Report upon a collection of Chermidae (Homoptera) from New Zealand. Trans. Proc. New Zealand Inst. 63 (1): 34-61, pls. 7-16.

Flor, Gustav (1861) : Zur Kenntniss der Rhychoten. Bull. Soc. Imp. Nat., Moscou $34: 331-422$.

Flor, Gustav (1861) : Die Rhychoten Livlands 2. Dorpat, E. J. Karow.

Förster, Arnold (1848) : Uebersicht der Gattungen und Arten in der Familieder Psylloden. Verhandlungen des natur. Ver. preuss. Rheinlande 5: 65-98.

Jensen, D. D. (1951): The North American species of Psylla from willow, with descriptions of new species and notes on biology (Homoptera : Psyllidae). Hilgardia, Berkeley 20: 299-324, 5 figs.

Jensen, D. D. (1957) : A new genus and five new species of Psyllidae from California and Lower California (Hemiptera). Wasmann J. Biol., San Francisco $15: 15-34,4$ pls.

Kuwayama, Satoru (1922) : Nippon San Kichi Kijirami-rui (A list of the known species of Japanese Psyllidae). Ins. World 26 (11): 365-374. (in Japanese).

Kuwayama, Satoru (1931) : A revision of the Psyllidae of Taiwan. Ins. Mats. 5 : 117-133, 2 figs.

Kuwayama, Satoru (1932) : Iconographia Insectorum Japonicorum pp. 1808 -1818.

Kuwayama, Satoru (1939) : On some species of Psyllidae from Amakusa. Zool Mag. 51: 535-537, 1 fig.

Kuwayama, Satoru (1943) : On some species of Psyllidae from Amami-Oshima and Yakushima. Trans. Nat. Hist. Soc. Taiwan $33: 504-511,3$ figs.

Kuwayama, Satoru (1955): A new species of Psyllidae from Japan (Homoptera). Mushi, Fukuoka $29: 1-3,1$ pl.

Kuwayama, Satoru (1961) : A new addition to the Psyllid-fauna of Japan (Hemip. tera-Homoptera). Ins. Mats. 24 (2): 123.

Kuwayama, Shigeru (1908) : Die Psylliden Japans I. Trans. Sapporo Nat. Hist. Soc. 2: 149-190, Tafel 3, 20 Figs.

Löw, F. (1877) : Beiträge zur Kenntniss der Psylloden. Verh. kaiser.-könig.zool. botan. Ges. Wien 27: 123-154.

Löw, F. (1878): Zur Systematik der Psylloden. Ibid. 28: 585-610.

Löw, F. (1882) : Revision der paläarktischen Psylloden in Hinsicht auf Systematik und Synonymie. Ibid. 32:227-25-2.

Makino, T. (1961) : Makino's New Illustrated Flora of Japan.

Matsumura, S. (1917) : Applied Entomology : 368-376.

Meyer-Dür (1872) : Die Psylloden. Mitt. schweiz. ent. Ges. 3 : 376-406.

Oshanin, B. (1907) : Verzeichnis der paläarktischen Hemipteren. Band 2, Homoptera pt. 2. Ann. Mus. 2001. Ac. Sc. 12 : 193-384.

Oshanin, B. (1912) : Katalog der palaearktischen Hemipteren (Psylliden). Verlag von R. Friedländer \& Sohn. Berlin : 125-129.

Priesner, H. (1927) : Eine neue Psylla-Artaus den Ostalpen. Konowia 6 : 263266, 7 figs.

Sasaki, K. (1954) : A list of the known species and their host-plants of the Psyllidae of Japan (Homoptera j. Sci. Rep. Matsuyama Agr. Coll. 14 : 29-39. 
(Sasaki, T. 1915): On Psylla malivorella Matsumura. Byo-tyugai Zasshi 2 (4): 301-304, figs.

Schmidberger, T. (1836) : Beiträge zur Obstbaumzucht und zur Naturgeschichte der obstbäumen schädlichen Insekten 4. Linz.

Shin ji, 0. (1938) : Five new species of Psyllidae from north-eastern Japan. Kontyû 12 (4): 146-151., 1 fig.

Shinji, 0. (1942) : Three new species of Psyllidae from Tokyo. Ins. World. 46 (1) : 2-5, 1 fig.

Sulc, Karel (1913) : Zur Kenntnis einiger Psylla-Arten aus dem Ungarischen National-Museum in Budapest. Ann. Hist.-Nat. Mus. Nat. Hungarici (Budapest) 11: 409-435.

Tuthill, L. D. (1943): The Psyllids of America North of Mexico (Psyllidae; Homoptera) (Subfamilies Psyllinae and Triozinae). Iowa St. Coll. J. Sci., Ames 17 : 443-667, 19 pls.

Tuthill, L. D. (1952): On the Psyllidae of New Zealand (Homoptera). Pac. Sci. 6 (2): $83-125,32$ figs.

Vondráček, K. (1957) : Fn. CCR : sv. 9 : Mery-Psylloidea. 431 pp. 265 figs.

Watanabe, F. (1937) : A catalogue of injurious insects of Japan :118-119.

Yu, F. L. (1956) : Notes on Psyllidae (Hemiptera) from Fukien and Taiwan, China (1). Mem. Coll. Agric. Nat. Taiwan Univ. 4 (3): 43-54, figs. 